\title{
Ecosystem change and human-environment interactions of Arabia
}

\author{
Sarah J. Ivory \\ Department of Geosciences and the Earth and Environmental Systems Institute \\ (EESI), Penn State University, University Park, USA \\ Michèle Dinies ${ }^{1}$ \\ Institute of Geographical Sciences, Freie Universität, Berlin, Germany \\ Anne-Marie Lézine \\ Laboratoire d'Océanographie et du Climat, Expérimentation et Approche \\ numérique/IPSL, Sorbonne University, CNRS-IRD-MNHN, Paris, France
}

\begin{abstract}
The Arabian Peninsula hosts some of the most extreme environments in the world. Arabian ecosystems are largely semi-arid to hyper-arid and yet are often highly biodiverse and unique owing to a location at a biogeographic nexus. There is an urgent need to better understand ecosystem resilience to biotic and abiotic disturbance; however, the modern vegetation across much of the sub-continent is still poorly understood. Palaeoecological records in Arabia have the potential to fill in gaps in our fundamental understanding of vegetation responses to climate, disturbance, and human modification; however, to do this, data must be accessible and easy to find. To this end, within the framework of the relaunch of the African Pollen Database, here we review existing palaeoecological datasets from the Arabian Peninsula, inventory those which are available, and synthesize results from these records. Due to the dearth of pre-Holocene information, this synthesis focuses on reconstructing vegetation from the Holocene Humid Period to today with emphasis on the impact of aridification and changing human livelihoods and culture on landscapes. Finally, as Arabia is perhaps the least well-studied region within the African Pollen Database, we offer some suggestions about fruitful directions for future palaeoecological research in this area.
\end{abstract}

\subsection{INTRODUCTION}

The Arabian Peninsula hosts some of the world's most extreme environments, including landscape gradients from montane woodland to cloud forest to active dune fields over small spatial scales, vast gravel deserts, and the world's largest sand sea, the Rub al'Khali. Its flora is complex biogeographically as well as ecologically very valuable (Kuerschner 1998). Due to its location

\footnotetext{
${ }^{1}$ Other affiliation: German Archaeological Institute (DAI), Scientific Department of the Head Office, Berlin, Germany
} 
near Asia, Europe, and Africa, the flora of the Arabian Peninsula includes a high percentage of plants with affinities to neighboring regions co-occurring in unique formations, with many plants that only grow in these harsh climates (Ghazanfar 1992).. Further, the deserts of Arabia are quite diverse, with the southern half situated within the Horn of Africa Biodiversity hotspot (Mittermeier et al. 2011).

The impact of climate change in Arabia is likely to put these fragile ecosystems at greater risk (Huang et al. 2017). Projections of climate that suggest that the "dry get drier" could further reduce moisture in a landscape already with a strong moisture deficit (Dahinden et al. 2017; Pachauri et al. 2014; Pausata et al. 2020). Further, the addition of increased rainfall variability could also intensify drought periods. Although many plants in the region are already adapted to arid and hyper-arid conditions, limited areas of grassland and woodland could undergo significant changes.

Further, despite climate being the main determinant of vegetation, land cover throughout the region is rapidly changing due to human activities (Alquarashi et al. 2016; Galletti et al . 2016). Rapid development following recent events, like the discovery of oil reserves in the Gulf States, has resulted in increased pressure on ecosystems as nations industrialize (Albalawi et al. 2018). Additionally, in much of Arabia, millions of people still live pastoral or agropastoral lifestyles and depend on ecosystem services for food, medicine, and fodder for animals (Ball et al. 2020). Freshwater availability is another important issue that can also be directly tied to vegetation. Ecosystem change associated with tree cover loss in wadis and southern Arabia is known to result in decreased surface water, declining water tables, and less spring discharge (Friesen et al. 2018; Hildebrandt et al. 2007). Thus, between the dual threats of climate and land-use change, it is important to better understand ecosystem changes in order to help develop sustainable management practices and validate models for an understudied region.

To this end, information is needed to better understand the relationship of Arabian vegetation to climate change on centennial timescales. Palaeoecological records, primarily from fossil pollen, provide key insights into the natural history and origins of the modern ecosystems in Arabia, feedbacks between climate and vegetation, ecosystem resilience, anthropogenic influences, and disturbance. In other regions, dense networks of these palynological records even allow for spatially explicit mapping of past vegetation (e.g. Dawson et al. 2016; Huntley 1990; Webb and McAndrews 1976; Williams and Jackson 2007). In contrast, Arabia is very data poor. This results form a few linked problems: 1) due to aridity, there is a lack of traditional palaeoenvironmental archives like lakes that have existed continuously through multiple climatic cycles, 2) access to regions that have potential for palaeoenvironmental work has become increasingly difficult due to evolving global politics, 3) existing pollen data from the region were housed within the African Pollen Database (APD), which lapsed in 2007 due to lack of funding, making accessibility of data also difficult. While these first two issues are a challenge to address, this paper, in conjunction with others in this special issue, emerge from an effort to renew and relaunch the APD (Ivory et al. 2020). This comes at a very critical time for using renewed, accessible data to synthesize the state of the art of palaeoecology in Arabia. Therefore, in this paper, we seek to: 1) review the state of current APD data holdings and those which have been generated since 2007, 2) synthesize these results from within the region in order to evaluate changes in vegetation since the Late Pleistocene, 3) provide recommendations for future work.

\subsection{MODERN SETTING}

The Arabian Peninsula (Figure 1) is situated in a complex geographical and geological setting between Africa, Asia, and the Mediterranean. Covering some 2.7 million $\mathrm{km}^{2}$, this sub-continent spans approximately $15^{\circ}$ latitude from the tropics to the subtropics (Kuerschner 1998). Because 
of active tectonism, Arabia is bordered on most sides by mountains, including the Zagros Mountains to the north, Hajar Mountains to the east, the Hijaz, Asir and Yemen Highlands to the west, and Dhofar Mountains and Hadramawt escarpments to the south bordering the Arabian Sea. In the continental interior, due to significant rain shadows from these highlands, Arabia hosts extensive arid and hyper-arid environments including three sand seas (Rub al'Khali, Nafud, Wahiba Sands; Figure 1).

The climate of Arabia involves both northern and tropical atmospheric circulation systems. Rainfall is generally low (Figure 2), with most areas receiving less than $100 \mathrm{~mm} / \mathrm{yr}$. This includes the hyper-arid interior and northwest coast $(<50 \mathrm{~mm} / \mathrm{yr})$, a large area from the Rub al'Khali (with 50-50mmyr), and c. 100mm/yr along the southern coasts. Notable exceptions to this are semi-arid regions in northern and southern Omani/Yemen mountains receiving c. $250 \mathrm{~mm} / \mathrm{yr}$, and the southwestern highlands in Yemen receiving $<400 \mathrm{~mm} / \mathrm{yr}$ (Almazroui et al. 2012; Fisher and Membery 1998). In the south, the summer rainfall is related to the yearly migration of the Intertropical Convergence Zone (ITCZ), which is located just south of the Oman/Yemen coasts in the summer months in its most northerly current position. However, despite the proximity of tropical convergence, southwesterly winds in June-July-August result in upwelling of cold waters off of the southern Yemen/Oman coast which limits evaporation of moisture into air masses. In this region, cool, damp winds encounter steep, coastal escarpments and form dense seasonal fogs in summertime (Fisher and Membery 1998; Hildebrandt et al. 2007). Thus, instead of rainfall, a portion of annual moisture received in the coastal mountains of Yemen and Oman occurs as dew or horizontal precipitation (Hildebrandt et al. 2007). Further, as a result of the trapping of moisture along the coasts, there is a strong rainshadow and many inland areas receive no reliable moisture at all. In the north, beyond the limit of summer moisture, northwesterly winds occur in the winter months. These winds are associated with mid-latitude westerly circulation. Rainfall typically occurs due to cyclonic systems that develop over the Mediterranean Sea. These systems bring gentle rainfall to the Near East and may also be funneled up along the Zagros Mountains to the Persian Gulf delivering moisture as far south as the United Arab Emirates (UAE) and northern Oman.

The vegetation in Arabia owes its character to tectonics, geology, relief, biogeographic histories of different adjacent regions, climate change, and human presence and cultural evolution (Figure 1; Kuerschner 1998). Large parts of the peninsula maintained strong floral affinities with Africa before separation of the continents due to rifting around 15 myrs ago (Kuerschner 1998). Since that time, evolutionary isolation from the tropical vegetation of Africa coupled with new biogeographic connections with Europe and Asia and drying during the later Cenozoic have strongly shaped vegetation structure and community composition (Patzelt 2015). Three main phytogeographical units are found: the Saharo-Sindian/Arabian regional zone, the SomaliMasai regional center of endemism, and an Afromontane phytogeographic unit similar to the high mountains of East Africa. These occur along with intruders in the north and southeast of Mediterranean and Irano-Turanian origin.

Beyond the coasts, the modern continental interior of the Arabian Peninsula is dominated by hyper-arid to semi-arid ecosystems dominated by plants with Saharo-Arabian affinities (Figure 1). These regions have sparse vegetation with extremely low ground cover in diffuse or contracted patterns on slopes or in depressions. A few scattered trees with tropical affinities such as Maeura crassifolia, Boscia arabica, and Acacia tortilis also occur. To the east, species composition changes to reflect the proximity of Asia in the Gulf of Oman desert and semi-desert, where tree communities commonly include Prosopis cineraria.

In the inland gravel and rock deserts, shrublands with Haloxylon salicornicum cover most of North Arabia, while shrublands with Rhanterium epapposum are most common in the eastern part of the Arabian Peninsula. Both formations constitute highly appreciated grazing resources. Shrublands with Calligonum comosum, Artemisia jordanica, and numerous annuals characterizes the Great Nafud and Dahna sands. In the hyper-arid Rub'al Khali, annuals are uncommon, and 


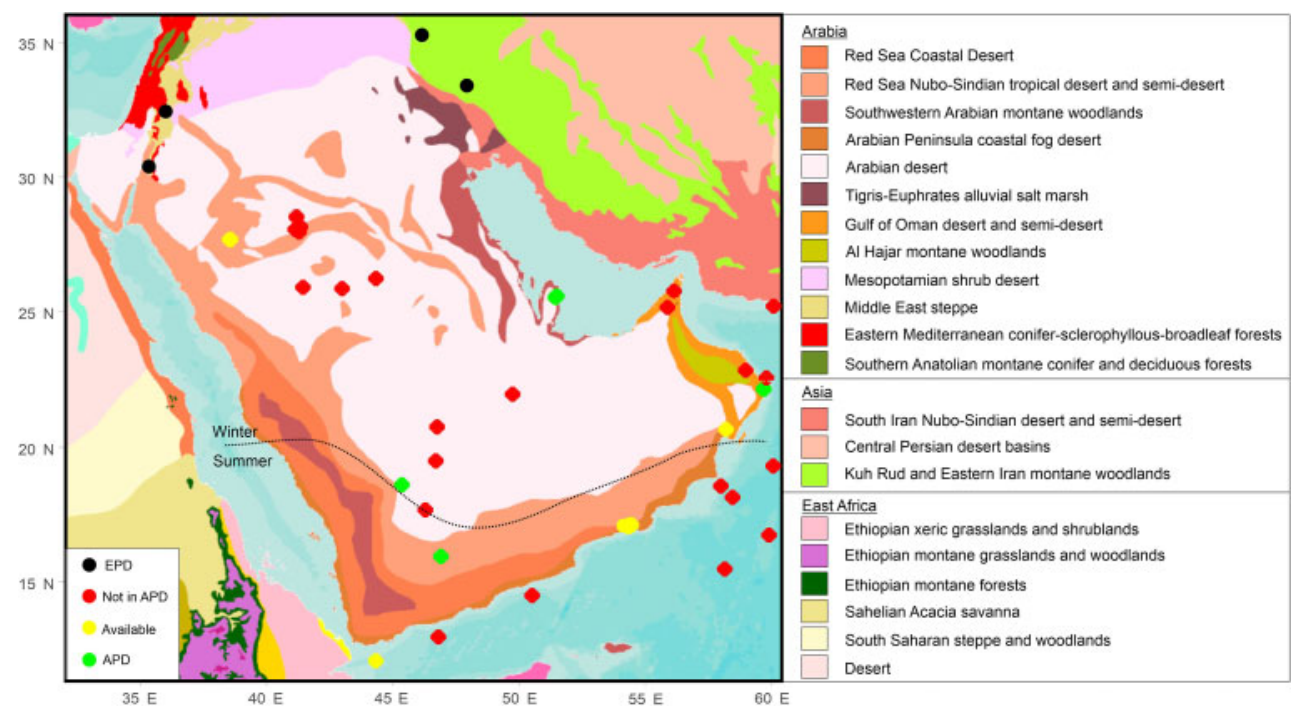

Figure 1. Map of terrestrial ecoregions of Arabia and adjacent areas (Olson et al. 2001). Dots indicate sites with datasets relevant to the African Pollen Database (APD), including those already in the APD data holdings (green), those available after 2007 (yellow), and those not within the APD (red). Black dots indicate datasets in the European Pollen Database (EPD). Dotted line indicates the boundary between dominant summer and winter rainfall.
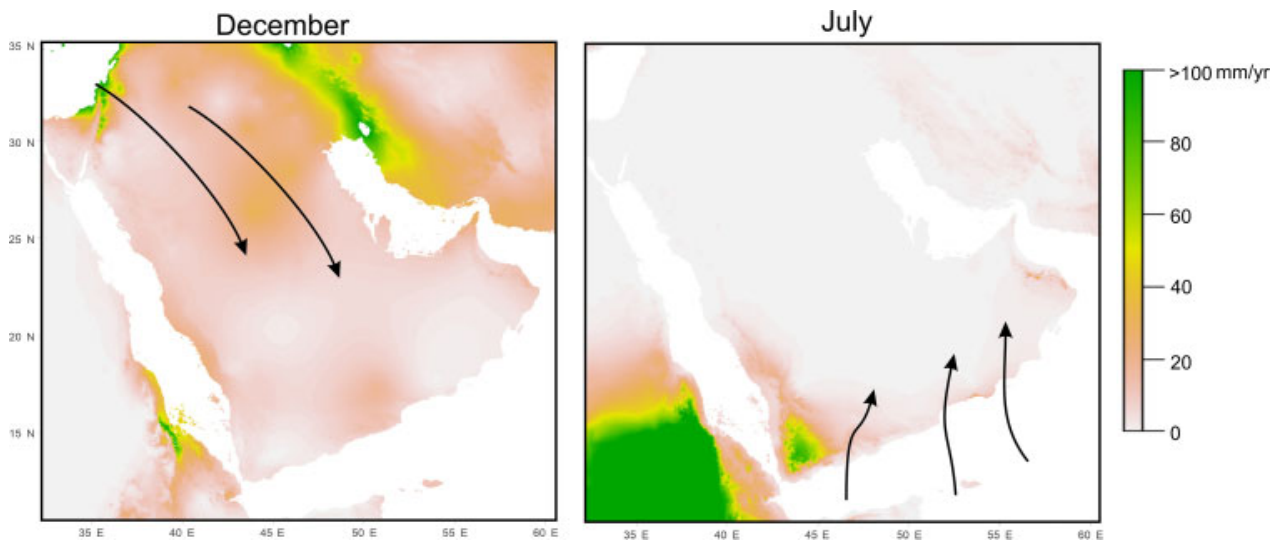

Figure 2. Map of rainfall throughout Arabia during December (left) and July (right). Average monthly precipitation at 2.5' resolution comes from Worldclim2 (Fick and Hijmans 2017). Arrows indicate direction of prevailing seasonal winds.

very open shrublands cover thousands of square kilometers, dominated by the endemic species Cornulaca arabica associated with Calligonum crinitum, Cyperus conglomeratus, and Tribulus arabicus.

Trees are mainly restricted to vegetation on mountain slopes, wadis, and coastal plains. Within the wadis, different Acacia species are accompanied by Mediterranean and Irano-Turanian taxa in the northern, northwestern, and southeastern regions, such as Nerium oleander. Sudanian taxa such as the toothbrush tree (Salvadora persica) are common in wadi communities in the southern part of Arabia. 
In the northernmost mountains, Mediterranean taxa play an important role. Steppic forests with pistachio (Pistacia khinjuk, P. atlantica) and juniper (Juniperus phoenicea) trees are found in the Hijaz Mountains. In the summit zone, oak-woodlands (with Quercus calliprinos) replace the juniper-pistachio woodlands.

In contrast, the southern and eastern mountains (Asir mountains, Yemeni highlands, the Hadhramaut Plateau and Dhofar Mountains) show a strong Afromontane affinity. Typical representatives are olive trees (Olea europaea subsp. cuspidata) in the western and southern Arabian mountains and juniper (Juniperus excelsa) at highest altitudes (Kuerschner 1998). Tree heathers (Erica arborea) in Yemen, the southwestern Asir mountains, and the southernmost Hijaz mountains are another example of the close floristic connections between East-Africa (Baierle 1993; Deil and al Gifri 1998; Ghazanfar 1992; Gil-Lopez et al. 2017; Kuerschner 1998; Mandaville 1998).

Other tropical African elements are representatives of the Somali-Masai AcaciaCommiphora phytogeographic zone along the Oman and Yemen coasts (Ghazanfar 1992; Mittermeier et al. 2011; Patzelt 2015). These include dense stands of seasonal woodlands and forests dominated by Terminalia (formerly Anogeissus; including the endemics T. dhofarica and T. bentii; Ghazanfar 1992). Some of these restricted patches owe their existence to seasonal summer fogs and increased rainfall along the south facing seaward slopes where the rainfall may exceed $250 \mathrm{~mm} / \mathrm{yr}$. However, due to several factors, including human modification from overgrazing and wood harvesting, expansive coastal deserts including savanna grasslands and rocky xeromorphic scrubland replace tropical deciduous woodland and forest today even at elevation in many locations (Ball et al. 2020).

Mangroves are also found at stream outlets leading to coastal estuaries (kwars or khors) in some locations along the southern coasts of Oman and Yemen (Deil 1998). In contrast with the freshwater dominated mangroves common in southwestern Asia, with species like Rhizophora mucronata, these Arabian mangroves are dominated by halophytic trees such as Avicennia marina. These environments have also become relatively degraded by human land-use and are intensively grazed by animals such as camels during the dry season.

\subsection{STATE OF RECORDS IN THE AFRICAN POLLEN DATABASE}

While Arabian palaeoecological records are quite few, their representation as a percentage of those in existence in data repositories such as the APD is also exceptionally low in comparison to other regions of Africa (Table 1). For this review, we consider only Arabian records south of the Levant for consideration, as Levantine and Near Eastern records have been contributed commonly to the European Pollen Database due to their Mediterranean affinity. The original data holdings of the APD dating to 2007 includes only 7 datasets. Within the framework of the relaunch of the APD, work has begun to inventory all Arabian records and encourage new data contributions. As a result, Table 1 shows that, of the 40 publications including pollen datasets, 9 new datasets have been contributed to date (total 16 Arabian records in APD). Several observations can be made of the emerging datasets produced within the last 15 years, including new archives previously unrepresented in Arabia (hyrax middens, archeological contexts, estuary sediment cores) which have resulted in an influx of new information to help answer ecological questions.

\subsection{VEGETATION HISTORY}

\subsubsection{Pre-Holocene}

Little palaeoecological information exists about the Cenozoic flora of Arabia prior to the Late Pleistocene, and none which falls under the convention of the African Pollen Database. The little 
Table 1. Inventory of all palynological records relevant to the African Pollen Database (APD).

\begin{tabular}{|c|c|c|c|c|c|}
\hline Type & $\begin{array}{l}\text { Site } \\
\text { Name }\end{array}$ & Latitude $\left({ }^{\circ} \mathrm{N}\right)$ & Longitude $\left({ }^{\circ} \mathrm{E}\right)$ & $\begin{array}{l}\text { Country/ } \\
\text { Ocean }\end{array}$ & Reference \\
\hline APD & Suwayh [Drill 2] & 22.09 & 59.67 & Oman & $\begin{array}{l}\text { Lézine et al. } \\
\text { (2002) }\end{array}$ \\
\hline APD & Suwayh [Drill 1] & 22.09 & 59.67 & Oman & $\begin{array}{l}\text { Lézine et al. } \\
\text { (2002) }\end{array}$ \\
\hline APD & Khor [F.B.] & 25.50 & 51.42 & Qatar & $\begin{array}{r}\text { Bonnefille and } \\
\text { Riollet (1988) }\end{array}$ \\
\hline APD & Khor M & 25.50 & 51.42 & Qatar & $\begin{array}{l}\text { Bonnefille and } \\
\text { Riollet (1988) }\end{array}$ \\
\hline APD & Site 36 & 25.53 & 51.50 & Qatar & $\begin{array}{l}\text { Bonnefille and } \\
\text { Riollet (1988) }\end{array}$ \\
\hline APD & Mundafan & 18.53 & 45.38 & Saudi Arabia & $\begin{array}{l}\text { El-Moslimany } \\
\text { (1983) }\end{array}$ \\
\hline APD & al-Hawa & 15.87 & 46.88 & Yemen & $\begin{array}{l}\text { Lézine et al. } \\
\text { (1998) }\end{array}$ \\
\hline APD & MD92-1002 & 12.03 & 44.32 & Indian Ocean & $\begin{array}{l}\text { Fersi et al., } \\
\text { (2016). }\end{array}$ \\
\hline available & SO90-56KA & 24.83 & 65.92 & Indian Ocean & $\begin{array}{l}\text { Ivory and } \\
\text { Lézine (2009) }\end{array}$ \\
\hline available & Filim & 20.60 & 58.19 & Oman & $\begin{array}{l}\text { Lézine et al. } \\
\text { (2017) }\end{array}$ \\
\hline available & Khawr Al Balid 1 & 17.00 & 54.34 & Oman & $\begin{array}{l}\text { Hoorn and } \\
\text { Cremaschi } \\
(2004)\end{array}$ \\
\hline available & Khawr Al Balid 3 & 17.00 & 54.33 & Oman & $\begin{array}{l}\text { Hoorn and } \\
\text { Cremaschi } \\
(2004)\end{array}$ \\
\hline available & Khawr Rawri 2 & 17.03 & 54.40 & Oman & $\begin{array}{l}\text { Hoorn and } \\
\text { Cremaschi } \\
(2004)\end{array}$ \\
\hline available & Khawr Rawri 4 & 17.03 & 54.41 & Oman & $\begin{array}{l}\text { Hoorn and } \\
\text { Cremaschi } \\
(2004)\end{array}$ \\
\hline available & Kwar al Jaramah & 22.50 & 59.77 & Oman & Lézine (2009) \\
\hline available & Sumharam & 17.04 & 54.43 & Oman & $\begin{array}{l}\text { Lippi et al. } \\
\text { (2011) }\end{array}$ \\
\hline available & Tayma & 27.63 & 38.55 & Saudi Arabia & $\begin{array}{l}\text { Dinies et al. } \\
\text { (2015) }\end{array}$ \\
\hline Not in APD & MD 77202 & 19.22 & 60.67 & Indian Ocean & $\begin{array}{l}\text { Van Campo } \\
\text { (1983) }\end{array}$ \\
\hline Not in APD & $\mathrm{RC} 27-14$ & 15.42 & 58.10 & Indian Ocean & $\begin{array}{l}\text { Overpeck et al. } \\
\text { (1996) }\end{array}$ \\
\hline Not in APD & $\mathrm{RC} 27-28$ & 18.50 & 57.98 & Indian Ocean & $\begin{array}{l}\text { Overpeck et al. } \\
\text { (1996) }\end{array}$ \\
\hline Not in APD & Hole 721B & 16.68 & 59.86 & Indian Ocean & $\begin{array}{l}\text { Van Campo } \\
\text { (1991) }\end{array}$ \\
\hline Not in APD & Hole 723 A/B & 18.05 & 58.44 & Indian Ocean & $\begin{array}{l}\text { Van Campo } \\
\text { (1991) }\end{array}$ \\
\hline
\end{tabular}


Table 1. Continued

\begin{tabular}{|c|c|c|c|c|c|}
\hline Type & $\begin{array}{l}\text { Site } \\
\text { Name }\end{array}$ & Latitude $\left({ }^{\circ} \mathrm{N}\right)$ & Longitude $\left({ }^{\circ} \mathrm{E}\right)$ & $\begin{array}{l}\text { Country/ } \\
\text { Ocean }\end{array}$ & Reference \\
\hline Not in APD & MD 76135 & 14.45 & 50.53 & Indian Ocean & $\begin{array}{l}\text { Van Campo } \\
\text { (1983) }\end{array}$ \\
\hline Not in APD & MD 76136 & 12.88 & 46.80 & Indian Ocean & $\begin{array}{l}\text { Van Campo } \\
(1983)\end{array}$ \\
\hline Not in APD & Maqta oasis & 22.77 & 58.96 & Oman & $\begin{array}{l}\text { Urban and } \\
\text { Buerkert } \\
(2009)\end{array}$ \\
\hline Not in APD & an Nafud [profil 2] & 25.85 & 41.43 & Saudi Arabia & $\begin{array}{l}\text { Schulz and } \\
\text { Whitney } \\
\text { (1986) }\end{array}$ \\
\hline Not in APD & an Nafud [profil 3] & 27.90 & 41.32 & Saudi Arabia & $\begin{array}{l}\text { Schulz and } \\
\text { Whitney } \\
\text { (1986) }\end{array}$ \\
\hline Not in APD & an Nafud [profil 4] & 28.02 & 41.15 & Saudi Arabia & $\begin{array}{l}\text { Schulz and } \\
\text { Whitney } \\
\text { (1986) }\end{array}$ \\
\hline Not in APD & an Nafud [profil 5] & 28.10 & 41.37 & Saudi Arabia & $\begin{array}{l}\text { Schulz and } \\
\text { Whitney } \\
\text { (1986) }\end{array}$ \\
\hline Not in APD & an Nafud [profil 6] & 28.45 & 41.22 & Saudi Arabia & $\begin{array}{l}\text { Schulz and } \\
\text { Whitney } \\
\text { (1986) }\end{array}$ \\
\hline Not in APD & an Nafud [profil 7] & 28.45 & 41.22 & Saudi Arabia & $\begin{array}{l}\text { Schulz and } \\
\text { Whitney } \\
\text { (1986) }\end{array}$ \\
\hline Not in APD & As-Sirr & 26.18 & 44.33 & Saudi Arabia & $\begin{array}{l}\text { Schulz and } \\
\text { Whitney } \\
(1986)\end{array}$ \\
\hline Not in APD & Djebel Asmar & 25.80 & 43.02 & Saudi Arabia & $\begin{array}{l}\text { Schulz and } \\
\text { Whitney } \\
\text { (1986) }\end{array}$ \\
\hline Not in APD & Jebel Ghiran & 20.66 & 46.73 & Saudi Arabia & $\begin{array}{l}\text { El-Moslimany } \\
\text { (1983) }\end{array}$ \\
\hline Not in APD & Rub'al-Khali & 19.43 & 46.69 & Saudi Arabia & $\begin{array}{l}\text { El-Moslimany } \\
\text { (1983) }\end{array}$ \\
\hline Not in APD & Rub'al-Khali [AS-3-1] & 21.88 & 49.72 & Saudi Arabia & $\begin{array}{l}\text { El-Moslimany } \\
\text { (1983) }\end{array}$ \\
\hline Not in APD & Rub'al-Khali [XX-B-5] & 17.59 & 46.30 & Saudi Arabia & $\begin{array}{l}\text { El-Moslimany } \\
\text { (1983) }\end{array}$ \\
\hline Not in APD & Awafi & 25.72 & 56.10 & UAE & $\begin{array}{l}\text { Parker et al. } \\
\text { (2004) }\end{array}$ \\
\hline Not in APD & Mleiha & 25.13 & 55.86 & UAE & $\begin{array}{l}\text { Garcia Anton } \\
\text { and Sainz } \\
\text { Ollero (1999) }\end{array}$ \\
\hline Not in APD & OS73 & 25.14 & 60.83 & Gulf of Oman & $\begin{array}{l}\text { Miller et al. } \\
\text { (2016) }\end{array}$ \\
\hline Not in APD & Sumharam & 17.04 & 54.43 & Oman & $\begin{array}{l}\text { Bellini et al. } \\
(2020)\end{array}$ \\
\hline
\end{tabular}


that can be inferred is based on the ancient biogeographic connection of Arabia with Eastern Africa. Prior to the inception of the East Africa Rift system, the Arabian and African plates were joined, forming a continuous stretch of land from what is now Ethiopia into southwestern Arabia (Yemen, Oman, and Saudi Arabia; Guba and Glennie 1998). This connection with Africa in the Eocene and Oligocene that sets the legacy of the modern floristic affinities with the African continent (Kuerschner 1998). By c. 30 Ma ago, the Arabian plate separated from Africa which likely had important consequences for the climate and flora of the region. Due to the relative biogeographic isolation of Arabia, endemic vascular plants emerged (Kuerschner 1998). During the last 10 myrs, global cooling led to increased aridity and the rise of $\mathrm{C}_{4}$ tropical savanna and open desert ecosystems. Pollen and carbon isotopes on leaf waxes from DSDP Site 231 in the Gulf of Aden suggest a transition to aridity by $10 \mathrm{Ma}$ and from $\mathrm{C}_{3}$ woodland to $\mathrm{C}_{4}$ savanna by c. $3.5 \mathrm{Ma}$ (Bonnefille 2010; Feakins 2013). Aridification progressed at the beginning of the Quaternary. Decreases in sea levels related to glacial-interglacial fluctuations in the Red Sea and Persian Gulf led to decreased biogeographic barriers with Africa and Asia, facilitating plant migrations when sea levels were low (Kuerschner 1998). This likely resulted in the inclusion of many elements of Irano-Sindian elements in plant communities of western and northern Arabia.

Over the late Quaternary, marine sediment cores from the Arabian Sea and Gulf of Aden along with very sparse terrestrial records provide information about climate and vegetation. Geomorphological studies of palaeolakes and dune mobilization coupled with observation speleothem growth phases suggest repeated oscillations of wetting and drying over at least the last $400 \mathrm{kyrs}$ (Figure 3; Burns et al. 2001; McClure 1984; Preusser et al. 2002; Rosenberg et al. 2011; Stokes and Bray 2005). This includes the development of inland lakes and aquifer recharge, such as have been observed during MIS5e in the Near East and Saudi Arabia (Issar and Bruins 1983; Petit-Maire et al. 2010; Rosenberg et al. 2011). $\delta^{18}$ O measured on benthic and planktic foraminifera from marine sediment cores MD77 202 and MD76 136 suggest that climate at least over the last $160 \mathrm{kyrs}$ was strongly related to glacial-interglacial cycles (Van Campo et al. 1982). In tropical Africa, palaeoclimate and palaeoecology are also mechanistically connected to eccentricity-modulated insolation as well as teleconnections with northern latitude glaciation; however, the record in Arabia is not long enough to resolve the impact of changes in tropical insolation on climate.

Regardless, pollen analysis on marine sediment cores MD77 202 and MD76 136 highlight enhanced aridity during glacial periods such as MIS 6 and MIS 2 characterized by high abundances of xerophytic herbs like Amaranthaceae (Figure 3). Despite relative wetness during interglacial periods, pollen assemblages appear to still contain many indicators that flora on the sub-continent has an important arid component. This includes high abundances of Asteraceae and Tribulus, but includes some more tropical elements, such as Acacia and higher abundances of grasses. This implies that coastal forests and mangroves may have expanded during interglacial periods (Fersi et al. 2016; Van Campo et al. 1982). In northern Arabia, drill cores from the Dead Sea provide insight into the environments from $c$. 147-89 ka. These show pronounced aridity through much of the penultimate glacial-interglacial transition with an abrupt transition to grass and woodland during the maximum interglacial from 124-115 ka (Chen and Litt 2018).

\subsubsection{Holocene}

Throughout the northern hemisphere tropics, the Pleistocene-Holocene transition was accompanied by an increase in summer insolation (Figure 4). This resulted in enhanced land-sea temperature contrasts which intensified northern tropical monsoon systems and is often referred to as the Holocene Humid Period (Mayewski et al. 2004). In North Africa, palaeoclimate and paleeoecological research has focused on evidence of extensive closed-basin lake systems like Lake Mega-Chad and the resultant northward migration of savanna and tropical woodland ecosystems to form the "Green Sahara" (Hély and Lézine 2014; Hoelzmann et al. 1998; Watrin et al. 


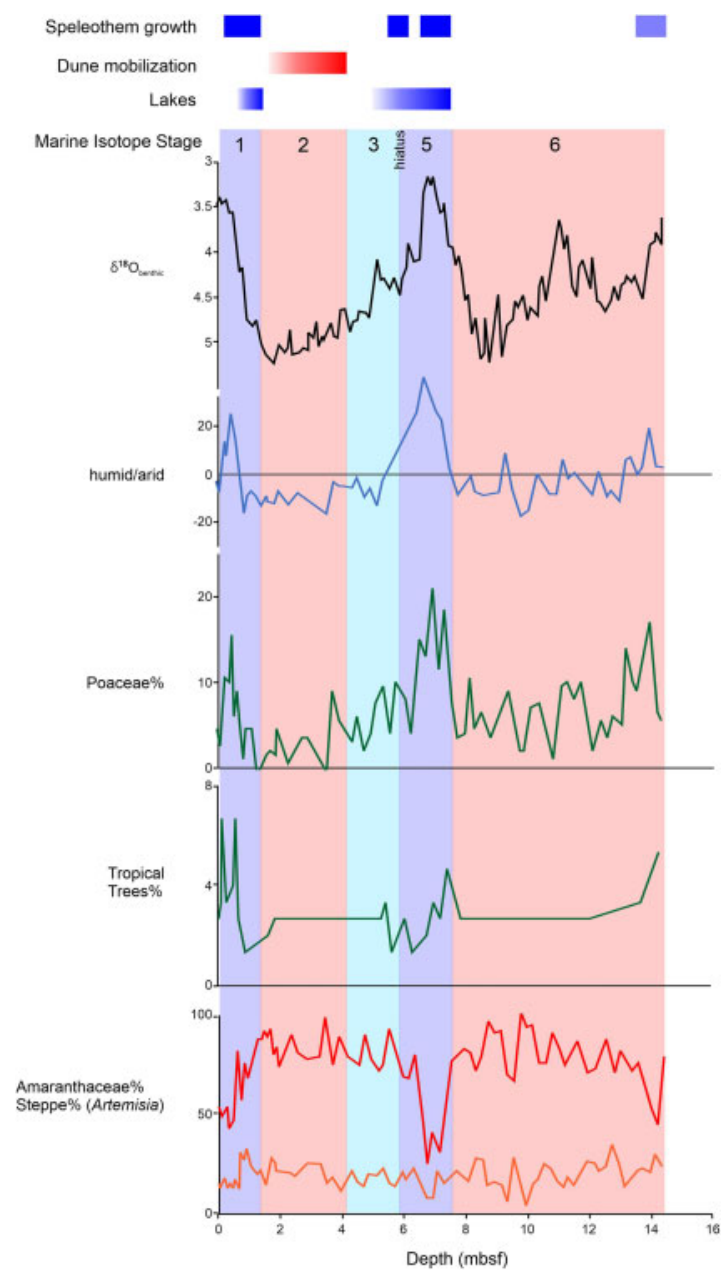

Figure 3. Late Quaternary climate and vegetation of Arabia, including (from top to bottom) indication of periods of speleothem growth (Burns et al. 2001), dune mobilization (Stokes and Bray 2005), closed basin lake deposits in Rub al-Khali (McClure 1984), geochemical and pollen data from marine sediment core MD77 202 including $\delta^{18} \mathrm{O}_{\text {benthic }}$, humid-arid index, and pollen abundances (Van Campo 1983).

2009). In Arabia, however, although changes in atmospheric circulation and teleconnections with the high latitudes resulted in increased rainfall during this time, the pattern is quite complex and varies regionally, particularly the response of the vegetation to enhanced rainfall.

\subsubsection{Palaeohydrology}

Palaeoclimatic studies of cave and lacustrine deposits demonstrate changes hydrology consistent with altered atmospheric circulation involving both a more northerly ITCZ and intensified Mediterranean moisture source during the early and middle Holocene from at least 9-6 ka across much of the Arabian Peninsula (Dinies et al. 2015; Enzel et al. 2015; Fleitmann et al. 2007, 2011; Lézine et al. 1998, 2007, 2009, 2014; Parker et al. 2004, 2006; Schulz and Whitney 1987). In southern Arabia, $\delta^{18} \mathrm{O}$ from speleothems collected across a latitudinal gradient from northern Oman (Hoti Cave, $22^{\circ} \mathrm{N}$ ) to southern Oman (Qunf Cave, $17^{\circ} \mathrm{N}$ ) show a depletion in 
oxygen isotopes attributed to the "amount effect" as well as indications of a southerly moisture source (Figure 4; Fleitmann et al. 2007, 2011). This implies increased tropical summer moisture associated with a northward migration of the ITCZ between 10-9 ka (Fleitmann et al. 2007, 2011;

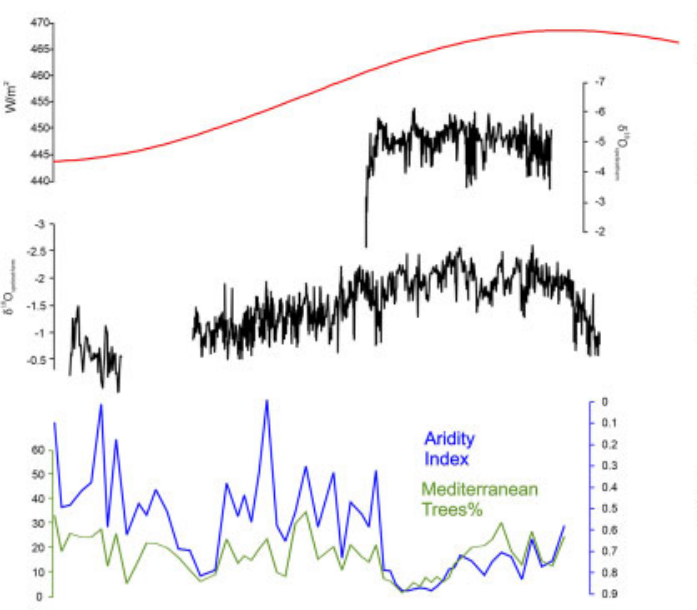

$15^{\circ} \mathrm{N}$ July

Insolation

Hoti Cave

$23^{\circ} 05^{\prime} \mathrm{N}$

Qunf Cav

$17^{\circ} 10 \mathrm{~N}$

Ein Gedi

$31^{\circ} 28^{\prime} \mathrm{N}$

Awafi

$25^{\circ} 42$ ' N

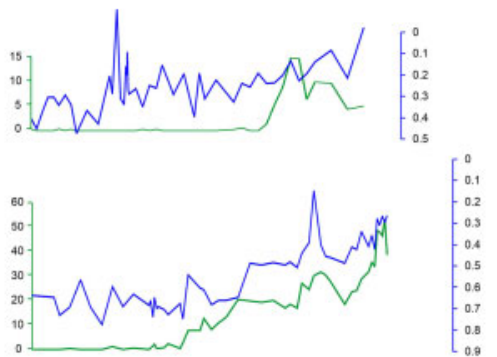

Kwar al Jaramah

$22^{\circ} 29^{\prime} \mathrm{N}$

Aridity
Index

Rhizophora

Mangrove\%

Filim

$20^{\circ} 36^{\prime} \mathrm{N}$

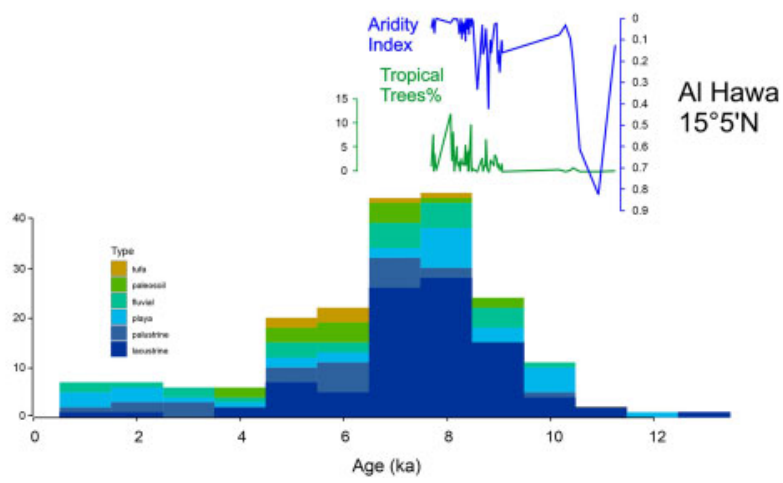

Figure 4. Holocene Humid Period climate and vegetation from Arabia including (from top to bottom) July solar insolation at $15 \mathrm{~N}$ (Berger and Loutre 1991), speleothem $\delta^{18} \mathrm{O}$ from Hoti Cave (northern Oman) and Qunf Cave (southern Oman; Fleitmann et al. 2007), aridity index and percent Mediterranean trees (Quercus/Olea/Juniperus) from Ein Gedi (Israel; Litt et al. 2012), vegetation at Awafi (UAE; Parker et al. 2004), aridity index and freshwater mangrove pollen (Rhizophora) from Kwar al Jaramah and Filim (Oman; Lézine et al. 2017), aridity index and percent tropical trees (Acacia, Dodonaea viscosa, Podocarpus, Ziziphus, Salvadora persica) from Al-Hawa (Yemen; Lézine et al. 1998), and frequency diagram of numbers of waterlain deposits (Lézine et al. 2014). 
Neff et al. 2001). Numerous studies link monsoon intensification to high summer insolation in the northern hemisphere at the early to mid-Holocene.

However, monsoon intensity based on marine core records responded non-linearly to radiative forcing with significantly centennial and millennial-scale variability (Gupta et al. 2003; Sirocko et al. 1993). This work suggests both direct and indirect forcing of the monsoon with variability mechanistically linked to teleconnections with both temperatures in the North Atlantic as well as changes in albedo over the Asian landmass. Although no quantitative estimates of rainfall increase are associated with those studies, palaeoclimate model simulations by Lézine et al. (2017) imply that large rainfall anomalies occurred in the south between $14-18^{\circ} \mathrm{N}$ at least as late as $6 \mathrm{ka}$ with increased summer moisture limited mostly to southern Oman and Yemen. Only marginal rainfall increase occurred as far north as $20-24^{\circ} \mathrm{N}$.

In addition to changes in tropical circulation, winter Mediterranean rainfall systems varied over the Holocene. Speleothem $\delta^{18} \mathrm{O}$ from caves in the Eastern Mediterranean, including Soreq Cave in Israel, lake level fluctuations, and the timing of sapropel deposition suggest that the winter rainfall zone underwent several transitions. Two major wetter phases were observed: an early Holocene Humid period (c. 10-7 ka) and a wetter phase at the end of the Middle Holocene, from c. 65-3 ka (Bar-Matthews et al. 1999; Bar-Matthews and Ayalon 2011; Litt et al. 2012; Migowski et al. 2004; Roberts et al. 2011; Robinson et al. 2006). This suggests an early phase of higher moisture associated with Mediterranean cyclonic systems coeval with early Holocene monsoon intensification in southern Arabia. However, unlike tropical Arabia, where indications of moisture persisted along the coast until 6-5 ka, the northern winter rainfall zone underwent a period of aridity during the mid-Holocene followed by renewed wetting after southern Arabia was already dry.

Higher rainfall across southern Arabia along coastal escarpments and highlands during the early Holocene resulted in increased streamflow into closed basins that comprise the continental interior. Waterlain deposits like lakes, ponds, and marshes are found that date to between 10-6 ka in southern Arabia (Figure 4; Enzel et al. 2015; Lézine et al. 2010). This includes palustrine deposits and extensive shallow endorheic lake systems in the Ramlat as-Sabatayn, Dhamar highlands in Yemen, and eastern fringes of the Rub al'Khali due to increased drainage from the landward sides of coastal escarpments (Davies 2006; Lézine et al. 1998; Parker et al. 2004). Wadis, or dry river valleys, which today rarely have flowing water, show evidence of fluvial activity during the early and mid-Holocene, including fine-grained deposits indicative of the development of permanent meandering streams in places like Wadi Sana, Yemen and Dhofar, Oman (Anderson 2007; Berger et al. 2012; Enzel et al. 2015; Sander 2006). Further, other geological evidence exists of groundwater recharge and higher water table from tufa and travertine deposits across Oman and Yemen which also date to the early Holocene (Cremaschi et al. 2015; Sander 2006). Carbonate-rich facies indicated by lithostratgraphic studies of the palaeolake deposits suggests that their development is due to enhanced runoff from adjacent highlands which trapped moisture rather than from direct rainfall onto lake surfaces (Lézine et al. 2007; Parker et al. 2004).

\subsubsection{Southern Arabian palaeoecology}

In southern Arabia, pollen, phytoliths, and macrobotanical remains show that the early Holocene was a period of major landscape transformation resulting in a reduction of arid and hyper-arid environments and expansion of diverse, savanna and woodland ecosystems due to increased moisture. As far north as $27^{\circ} \mathrm{N}$, which today is largely outside of the summer southwest monsoon zone, phytolith, carbon isotopes, and pollen analysis from a palaeolake deposit at Awafi demonstrate the development of $\mathrm{a}_{3}$ Pooid grassland with higher abundances trees like Acacia, Tamarix, Prosopis, and palms occurred from 9-6 ka (Parker et al. 2004). At Suwayh, along the northern Omani coast, increased abundances of grasses and some tropical trees is in agreement with denser vegetation with many taxa with Somali-Masai affinities (Lézine et al. 2002). To the southwest, in Wadi Sana in Yemen, pollen and macrobotanical evidence from hyrax middens and alluvial sediments demonstrates the development of woodland with a dense grassy understory along a permanent stream until at least 6-5 $\mathrm{ka}$ (McCorriston et al. 2002). This woodland included 
a keystone tree taxon from coastal seasonal woodlands (Terminalia dhofarica), which during the mid-Holocene, appears to have had a more continuous range across coastal highlands, but also may have extended further inland along waterways (Oberprieler et al. 2009).

However, despite the expansion of tropical savanna and woodland in some locations in southern Arabia during the early and mid-Holocene, there are also many indications of persistent aridity. This suggests strong heterogeneity in local moisture and therefore strong local controls on vegetation. For example, pollen analysis also demonstrates the stability of many xerophytic taxa throughout this interval. Although pollen analysis on the palaeolake sediments suggest that the lake margin vegetation was dominated by local aquatic plants (Typha) due to the presence of water, the terrestrial flora around the lake was characterized by Arabian desert plants like Cyperaceae, Calligonum, and Amaranthaceae, common in the modern flora (Lézine et al. 1998, 2007). This is true as well in pollen records from coastal estuaries, which integrate pollen from a large regional watershed. For example, at Filim and Kwar al Jaramah along the Oman coast, desert taxa (Artemisia, Cyperaceae) increase in abundances after 6-5 ka but are a dominant component of the pollen spectra even prior to this (Lézine et al. 2017). These regionally integrating records do however support the idea of localized changes in vegetation structure and composition in distant headwaters. For example, at Al-Hawa, long distant transport of pollen from Afromontane and tropical woodland trees (Podocarpus, Erica, Juniperus) that are not observed today in modern pollen rain occurred in small abundances until the desiccation of the palaeolake around $7.2 \mathrm{ka}$ (Lézine et al. 1998, 2007). This supports that idea that tropical African elements occurred more abundantly in the mountains that drain into the Ramlat as-Sabatayn and that these mountains likely acted as strong topographic barriers to rainfall even during times of enhanced monsoon intensity. This suggests that in contrast to widespread expansion of wetter biomes in Northern Africa, Arabian ecosystems even during the Holocene Humid Period were always on the margins of desert, perhaps due in part to the complex topography.

An additional impact of increased freshwater flux from heavier rainfall in southern Arabia during the Holocene Humid Period was the presence of Rhizophora mangrove vegetation throughout coastal estuaries. Today, mangroves are found only in very limited patches along the southern Arabian coast (Deil 1998). Further, species composition of modern mangroves is closely related to water chemistry, particularly salinity, within an estuary. For example, most mangroves remaining in arid and semi-arid regions are typically dominated by the halophytic taxon Avicennia marina. While this tree is also present in the early to mid-Holocene, increased abundances of mangrove pollen taxa that do not tolerate high salinity, such as Rhizophora, can only occur in the presence of increased freshwater flux from the land. Rhizophora pollen occurs in high abundances in sediments before $4 \mathrm{ka}$ along the southern Arabian and east Asian coasts at Kwar al Jaramah, Suwayh, and Filim as well as being present in Arabian Sea marine sediment cores (Lézine et al. 2017). This suggests that increased freshwater runoff into coastal estuaries altered their water chemistry, allowing taxa like Rhizophora which do not tolerate very saline conditions to thrive during the mid-Holocene.

\subsubsection{Northern Arabian palaeoecology}

In northern Arabia, the record of early to mid-Holocene vegetation is quite different from southern Arabia. In particular, there is a marked difference in the timing of the maximum in Holocene moisture latitudinally from subtropical northern to tropical southern Arabia. Based on compilations of hydrological records from southern Arabia, Lézine et al. (2014) demonstrated that the Holocene Humid Period maximum was coeval at tropical sites and occurred from 10-6.5 ka. In contrast, in the subtropics, $\delta^{18} \mathrm{O}$ measurements on lacustrine sediments suggest increased winter moisture from 9-8 ka, with a marked arid interval from 8-6 ka despite continued winter rain influence (Bar-Matthews et al. 1999; Litt et al. 2012; Roberts et al. 2011; Stevens et al. 2006). Lithostratigraphic observations and pollen analysis from Lake Mirabad in Iran suggest warm and dry conditions at this time favored a more arid, open vegetation characterized by low abundances 
of tree pollen in comparison to today (Van Zeist and Bottema 1977). Further south along the Dead Sea, lake level fluctuations indicate an early Holocene Humid Period (10-8.6 ka), increased aridity during 8-5.6 ka, and another phase of raised lake level indicating increased humidity during 5.6-3.5 ka (Migowski et al. 2006). The early Holocene vegetation transitions based on the core from the shoreline at Ein Gedi demonstrates low proportions of Mediterranean tree pollen such as deciduous oak, and scattered pistachio and olive pollen probably originating from the adjacent mountains. Amaranthaceae, together with Poaceae, Artemisia, Ephedra, and Asteraceae are the main constituents, associated to the Saharo-Arabian and Irano-Turanian biomes, indicating increased winter temperatures (Litt et al. 2012). A milder winter during early Holocene is in line with the increase of pistachio during this period in the Mediterranean (Rossignol-Strick 1999). Further south into Saudi Arabia, pollen from the Tayma record show regionally wetter conditions associated with increased Mediterranean woodlands (Quercus, Pistachia) in the Hijaz mountains in the west and expanded grasslands during the early Holocene only until $8 \mathrm{ka}$ (Dinies et al. 2015, 2016). Other shallow lake sediments from the early Holocene corroborate an increase in humidity in this region (Crassard et al. 2013, Guagnin et al. 2017, Petraglia et al. 2020). At about $8 \mathrm{ka}$, a distinct vegetation shift at Tayma occurred, characterized by the retreat of grasslands and the re-expansion of desert dwarf-shrubs (i.e. Haloxylon type). This indicates the onset of arid conditions lasting at least until $4000 \mathrm{yrs}$ BP, when the shallow-water lake dried out (Engel et al. 2012). Four pollen records (2-4 samples each) from diatomites in interdune depressions in the Nafud sand desert date to $9.5-5.8 \mathrm{ka}$ and are similar to modern pollen spectra, pointing to persistent arid conditions throughout the Holocene (Schulz and Whitney 1987).

In the northern subtropics and into the Near East, winter moisture associated with enhanced westerly cyclonic activity increased at $6.5 \mathrm{ka}$. This is in agreement with palaeoecological work from Israel and Northern Jordan showing the expansion of Mediterranean forests with deciduous and evergreen oaks and olives (wild and/or cultivated) to lower elevations than present. At this same period, high lake levels at Dead Sea occurred between 6.3-3.3 ka (Litt et al. 2012). Indications of enhanced winter cyclonic moisture at this time extend into tropical Arabia, where Parker et al. (2004) observed a relatively stable period of mixed $\mathrm{C}_{3}-\mathrm{C}_{4}$ grassland and steppe at Awafi long after summer moisture had retreated from this region. However, there are no indications for wetter conditions in the more southern part of northwestern Arabia, where dwarf shrub steppe dominated until $4.2 \mathrm{ka}$.

\subsubsection{Characteristics of the Arabian Holocene Humid Period}

Modeling and empirical studies have focused on determining if the termination of the Holocene Humid Period in the tropics and the retreat of the ITCZ was abrupt or gradual. Within Arabia, in particular, a contrast is observed in the apparent pace of hydrological and ecological change recorded in marine versus terrestrial settings (Lézine et al. 2014). Marine sediment cores from the Indian Ocean and Arabian Sea capture dust sourced from deserts of Arabia and East Africa during periods of dry or windy climate (Sirocko et al. 1993). Throughout the early Holocene, abrupt transitions associated with centennial-millennial scale variability in monsoon intensity are observed (Gupta et al. 2003). Further, at the end of the Holocene Humid Period, dust influxes rose in several of these cores, interpreted as abrupt reduction of moisture in the region and increased dust transport (Sirocko et al. 1993). However, few terrestrial archives of both climate and palaeoenvironmental information capture this abrupt variability or termination. Speleothem $\delta^{18} \mathrm{O}$ from southern Arabia exhibit a time transgressive reduction in rainfall (Fleitmann et al. 2007). At Hoti Cave in Northern Oman, a relatively rapid enrichment in $\delta^{18} \mathrm{O}$ occurs at $c .6 \mathrm{ka}$ leading to a hiatus marking the initial southward retreat of the ITCZ and a decrease in summertime moisture around $23^{\circ} \mathrm{N}$. Further south at Qunf Cave $\left(17^{\circ} \mathrm{N}\right)$ along the Arabian Sea, $\delta^{18} \mathrm{O}$ instead followed a gradual enrichment beginning just after $6 \mathrm{ka}$ and continuing until a depositional hiatus at around $2.5 \mathrm{ka}$. This gradual decline in rainfall is in agreement with palaeoclimate simulations across similar latitudinal transect, which suggest more northerly sites saw a more abrupt, earlier 
decline in rainfall than southern sites (Lézine et al. 2017). Further evidence of a progressive decline in moisture comes from Lézine et al. (2014) who synthesized ages of waterlain deposits as indications of changes in rainfall. This analysis also suggests a gradual disappearance of surface water until c. $6 \mathrm{ka}$, when most areas dried up. Most palaeoecological records from southern Arabia also agree that ecosystem change followed a similar gradual transition toward semi-arid and arid ecosystems which resemble modern biomes, particularly after $6 \mathrm{ka}$. At Awafi, this time marked the transition back to from $C_{3}$ to mixed $C_{3}-C_{4}$ savanna (Parker et al. 2004). Macrofossils and pollen from hyrax middens from Wadi Sana, Yemen, show a transition from gallery woodland to semi-desert with an increase in Artemisia and Amaranthaceae (McCorriston et al. 2002). Along the coasts in estuaries, declining freshwater inputs result in a relatively gradual decline in freshwater mangrove taxon, Rhizophora, in favor of saltwater mangroves (Lézine et al. 2017).

Increases in rainfall and decreased rainfall seasonality throughout the Arabian Peninsula during the early to Mid-Holocene resulted in the development of ecosystems whose composition and dynamics were not analogous to those found today. In fact, most pollen spectra prior to $6 \mathrm{ka}$ are difficult to compare directly with pollen samples representing modern vegetation (El-Moslimany 1990; Lézine et al. 2010). We illustrate some examples of these in Figure 5 which shows affinities of pollen taxa to modern phytogeographic regions. In this figure, most palaeoecological sites presented here have affinities based on pollen assemblages to multiple modern vegetation types. Here we will demonstrate those primary and secondary affinities to modern vegetation for no analog pollen spectra.

For example, in the Near East at Wadi Faynan, increases in arboreal taxa from at least 8-6 ka suggest that SW Jordan hosted woodlands along waterways and expanded montane forest communities (Hunt et al. 2004). Although many of these still occur either at the site or at least within the region (Juniperus, Quercus) today, Ulmus is not recorded in modern samples in that region. This is true for southern Arabia as well. For example, in Wadi Sana, in the modern stony desert, occasional trees such as Maerua and Acacia are observed. In the mid-Holocene, in addition to higher pollen abundances of these common modern arboreal taxa, higher abundances of trees with tropical affinities only were found at the southernmost coast, such as Terminalia, Olea, and Dodonea viscosa were also an important part of the arboreal community (McCorriston et al. 2002; Ivory et al., 2021). However, it is important to note, that as discussed above, much of southern as well as northern Arabia remained arid or semi-arid even at the peak in the monsoon, thus we suggest that these changes in vegetation composition are likely linked to the presence of increased surface water amidst persistent climatic aridity.

Finally, the increase in biomass during the early to Mid-Holocene also appears to have resulted in a change in the dynamics of wildfires in some location in Arabia. Today throughout Arabia, wildfire is extremely uncommon due to lack of fuel and continuity of fuel on the landscape because of extreme aridity (Cao et al. 2015). Charcoal and microcharcoal datasets are rarer even than other palaeoecological information; however, increased charcoal deposition in palaeolake deposits, hyrax middens, and even the appearance of burnt surfaces in fine-grained stream deposits is a testament to the increase in fuel locally, linked to higher rainfall seasonality (Kimiaie and McCorriston 2014; McCorriston et al. 2002). Further, there are indications of increased inputs of charred plant material during this time coeval with increased land use and oasis cultivation, suggesting a relationship between fire and human presence (Dinies et al. 2016).

\subsection{COUPLED HUMAN AND NATURAL SYSTEMS}

Modern humans may have been present in Arabia for much of the Late Pleistocene. Arabian geography in fact likely played a strong role in early human migration (Armitage et al. 2011; Petraglia 2011). Environmental change, mainly hydrological variations related to glacial-interglacial cycles and monsoon intensity, is thought to have contributed to the movement of early humans out of 


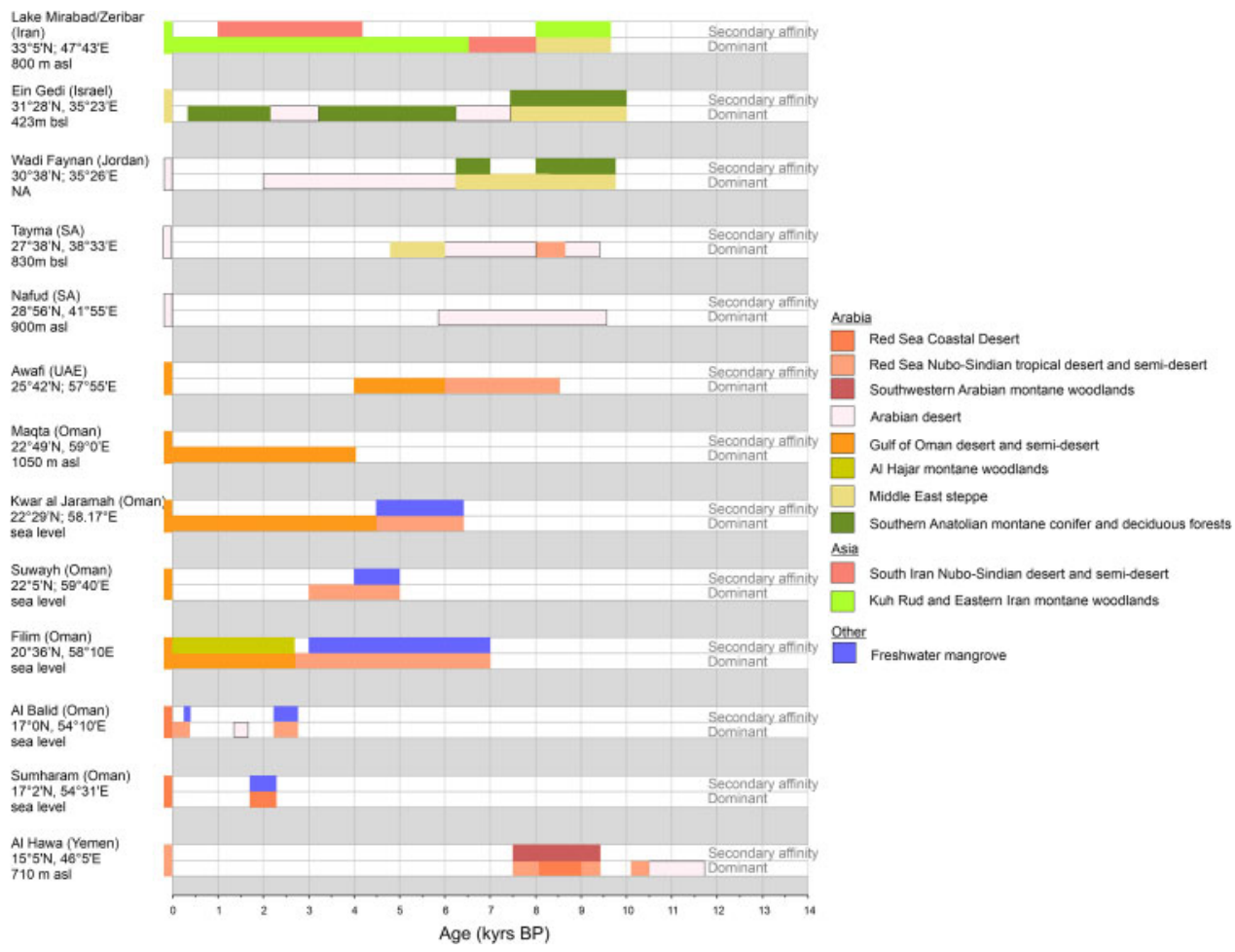

Figure 5. Holocene vegetation affinities in relation to ecoregion species composition as presented in Figure 1. For each site, there are two rows which represent the primary vegetation affinity (lower row) as represented by the pollen assemblages and the secondary affinity (upper row) in the case that pollen assemblage composition differed substantially from modern assemblages for numerous reasons (long distance transport, no modern analog, presence of significant aquatic vegetation).

Africa and continuous human presence (deMenocal and Stringer 2016; Tierney et al. 2017). Increasing evidence exists of earlier lacustrine phases in central Arabia which could have supported a more resource-rich landscape into which early hunter-gathers may have migrated (Parker 2010). Further, low sea levels during glacials, particularly along the Red Sea as well as the gulfs to the east, would have facilitated migration of early humans as they may have for plants (Lambeck 1996; Lokier et al. 2015). Evidence from mitochondrial DNA implies populations present in Arabia at least as early as $60 \mathrm{ka}$ (Fernandes et al. 2015); however, direct archeological evidence of this time is scarce. For example, lithic piles are commonly observed throughout Arabia, but limitations in dating complicates an assessment beyond morphological attribution of assemblages to at least Early and Middle Palaeolithic (Groucutt and Petraglia 2012; Rose and Usik 2010). Little palaeoecological evidence exists beyond marine sediment cores to provide an environmental context of these migrations or potential footprint of these early hunters on the landscape. Evidence was preserved only from the Neolithic and the onset of the Holocene Humid Period to suggest continuous human presence throughout much of the sub-continent.

During Late Pleistocene and Holocene, human-environment interactions in Arabia began to shift through accelerated technological advancements. Notably, the cultivation and domestication processes of annual plants started in the Fertile Crescent at this time. Numerous studies point to a long-lasting, multi-phased, and multi-centered domestication process of cereals and pulses, connected to multiple triggers including climatic changes as well as cultural and demographic 
developments (e.g. Fuller et al. 2012; Hillman et al. 2001; Willcox 2012; Zeder 2011). These innovations are at the origin of far-reaching landscape transformations resulting in highly anthropogenic ecosystems such as gardens and fields. Perennial fruit trees such as olive and grapes were also domesticated and propagated from 9-6 ka (e.g. Zohary 1982). However, a much earlier start of these processes cannot be excluded for fruit trees, as indicated by the supposed early beginnings of domestication of figs near $11.4 \mathrm{ka}$ (Kislev et al. 2006).

The spread of these Near Eastern domesticates into the Arabian Peninsula, the introduction of cultivars from other domestication centers such as African crops in Southern Arabia (e.g. millet; Tengberg 2003), and autochthonous agricultural developments on the Arabian Peninsula are not well known. With the exception of the southern mountains, modern precipitation is too low to practice durable dry-land farming which requires at least $250 \mathrm{~mm} / \mathrm{yr}$ rainfall (e.g. Thalen 1979). Buried early-to-mid Holocene soils in Yemen show the potential for local agriculture during this wetter period, however these conditions have been lacking since Bronze Age (Pietsch et al. 2010). Arable farming thus was restricted to hydrologically favorable sites in most parts of the Arabian Peninsula, such as natural oases and wadis or depending on the development of irrigation. Terracing slopes or wadi beds are other basic features connected to gardening and oasis cultivation, (e.g. Avni et al. 2012; Buerkert and Schlecht 2010), often combined with run-off water harvesting installations at least in the past. The complex nature of sedimentary deposits from terraces and wadi beds is challenging for palaeoecological investigations. For example, these terrace features have fluvial accumulation resulting in discontinuous sedimentation, re-deposition, and often missing preservation of organic material. However, interdisciplinary research approaches indicate the potential in deciphering the fluctuating multiple uses, plant cultivation, and grazing during the past (Beckers et al. 2013; Charbonnier et al. 2017; Meister et al. 2016; Moraetis et al. 2020; Purdue et al. 2019) These basic landscape features necessitated adapted agricultural systems such as oasis agriculture, characterized today by it's a combination of cultivation of perennial fruit trees and annual crops.

Neolithic archeological assemblages in the Nafud, the northern sand desert of Saudi Arabia, show a strong Levantine influence (Crassard et al. 2013), while southern Arabian archeological findings point to the persistence of regional agricultural developments. Archeo-zoological records of domesticated sheep, goats, and cattle since the $8 \mathrm{ka}$ point to connections to the Near East as well. Herding (and hunting) is thought to have been a major subsistence strategy since at least the Neolithic (c. 7-6 ka). Somewhat more favorable environmental conditions during the early to mid-Holocene, i.e. denser and more diverse vegetation, facilitated the spread of this new livelihood (Crassard and Drechsler 2013; Uerpmann et al. 2010). Its impact on natural ecosystems on a regional level is quite difficult to estimate. In southern Jordan, vegetation disturbance due to grazing is supposed to be small as compared to the impacts in later times by industrial activities such as ore production (Hunt et al. 2007). In southern Arabia in particular, decades of research have focused on the observation that southern Arabian populations seem to have adopted agriculture relatively late in comparison with the Gulf region (within the last 3-2 ka; Harrower et al. 2010; McCorriston 2013; McCorriston and Johnson 1998). Instead, Late Stone Age and Bronze Age people in southern Arabia retained pastoral livelihoods through much of the Holocene. Throughout Yemen and Oman, evidence of ephemeral camps exist in the highlands as well as in the inland draining wadis and around palaeolake shorelines, suggesting mobile lifestyles centred around animal-husbandry of cattle and goats by $8 \mathrm{ka}$, and eventually camels by 3.5ka (Lézine et al. 2010; Martin et al. 2009; McCorriston 2013).

However, despite the adoption of agriculture in southern Arabia, there is still some equivocal palaeoecological evidence for human environmental modification of the early to mid-Holocene landscape by nomadic pastoralists. In Wadi Sana, Yemen, evidence of burned surfaces and hearths contained in terrace sediments are coeval with evidence of dated occupation by pastoralists (Kimiae and McCorriston 2014; McCorriston et al. 2002). This suggests that the practice of controlled burning of the landscape to deter woody encroachment and promote tender grassy 
shoot production for animal fodder, a practice common in modern pastoralist groups, may have been used at this time (Kimiae and McCorriston 2014). Hearths and settlement excavations from southern Oman and Yemen attest to wood harvesting, particularly taxa known for use as fodder, construction materials, or cooking fuel including Acacia, Terminalia, and Ziziphus. This evidence of fire and landscape modification is also visible in pollen and macrobotanical remains preserved in hyrax middens near archeological sites in Yemen (McCorriston et al. 2002; Ivory et al., 2021). Further, following the initial decline in monsoon moisture around $6 \mathrm{ka}$, construction of simple check dams and irrigation features is observed along wadis in Oman and Yemen (Harrower 2008). This is also contemporaneous with the increase in construction of falaj systems in northern Oman to provide an additional source of freshwater in the lowlands. These water management structures are thought perhaps to mitigate increased moisture variability and decreased surface runoff associated with declining monsoon intensity prior to abandonment of the region around $5 \mathrm{ka}$ (Harrower 2008).

The cultivation of crops however is unambiguous evidence of anthropogenic changes. Although pollen of Cerealia is present in moderate abundances as early as $10 \mathrm{ka}$ in sediment cores (Hunt et al. 2004; Litt et al. 2012), these very few early Holocene pollen records do not offer clear clues due to the challenge in reliably distinguishing wild grasses from domesticated cereals on the Arabian Peninsula. However, since the $5 \mathrm{ka}$, the cultivation of cereals and other annuals is attested by seeds and fruits for different regions on Arabian Peninsula, indicating connectivity with the Near East (Boivin and Fuller 2009; Bouchaud et al. 2016). In the Gulf region, records of Phoenix dactylifera predate the cereals, and so far, the oldest date palm kernels are found on the Dalma islands dating to $c .8 \mathrm{ka}$ (Beech and Shepherd 1994), with otherwise marine food remains dominating. Since $5 \mathrm{ka}$, the date palm seemed to have played an important role in the arable agriculture of the gulf region, while in other regions of the Arabian Peninsula, this now dominant tree was still missing (e.g. Schiettecatte et al. 2013) and oasis agriculture relied on other fruit trees such as grapes (Dinies et al. 2016).

The crop evidence since $c$. 5-4 ka agree with the emergence of large oasis settlements and increased connectivity, including maritime trade (e.g. Boivin and Fuller 2009; Hausleiter and Eichmann 2018). The storied "incense road" may be seen as part of this connectivity. Ongoing residue analyses in the oasis of Tayma, NW Arabia, point to likely local resin sources (Pistacia, Commiphora) during late mid-Holocene, while Boswellia became important during the last 30002000 years. The commercial harvest and trade of Boswellia resin (luban, frankincense) resulted in the construction of seaports such as Sumharam and Al Baleed in southern Oman to facilitate trade of frankincense along Arabian Sea trade routes (Hoorn and Cremaschi 2004; Lippi et al. 2011). Here too, the impact of oasis agriculture on the landscape on a regional scale is hard to estimate due to the very few palaeoecological records and probably varied depending on the local practices. Detailed archeobotanical analyses of a NW Arabian oasis indicate the persistence of desert vegetation without major shifts, pointing to exploitation of available natural resources, but no over-use (Bouchaud 2011). The modern heavily overused landscape situation seems to differ from that prevailing even just a few centuries ago, when grazing (and wood/shrub cutting) was restricted because of a missing permanent water supply. This today has become obsolete because of deep wells and mobile water tanks guaranteeing accessibility everywhere (Hunt et al. 2007; Thalen 1979).

\subsection{CONCLUSIONS}

The vegetation of Arabia is strongly imprinted by biogeographic and palaeoecological processes that unfolded over millions of years beginning with the separation from Africa during the Cenozoic. Although little empirical palaeoecological data exist, new efforts to relaunch the African Pollen Database including Arabia will galvanize new research efforts as well as syntheses by 
conforming to FAIR data standards that make existing data easier to find and work with (Ivory et al. 2020; Wilkinson et al. 2016). This review attempts to summarize some of this work and inventory data holdings currently within the APD.

Palaeoecological information from Arabia make it clear that while ecologically diverse and endemic, Arabian ecosystems have existed on the edge of extreme aridity for at least hundreds of thousands of years. We recognize the strong need for more palaeoecological data which represent pre-Holocene time periods in order to better disentangle the influence of climate events on the vegetation. Although deep, long-lived lakes are rare in the region, analysis of pre-Holocene palaeolake deposits as well as drilling campaigns in estuarine sites could help fill in some of this gap. Further, despite the highest data density within the early Holocene, these data are still very sparse. Improving spatial and temporal resolution of this period should also be considered a priority. This may be achieved by continued work on classical palaeoecological archives (palaeolakes, oases), complementing archeological investigations with archeobotanical research, and the development of novel palaeoecological archives adapted to arid regions such as hyrax middens, termite mounds, and fine-grained fluvial deposits.

The antiquity of the human legacy on the environment is not well known. The human imprint on the landscape in Arabia locally is strong through crop cultivation in oases or wadis but seems to be reversible and without indication of over-use in vast desert and semi-desert regions used as rangelands. The density of palaeoecological information associated with archeological investigations do not lend themselves to a very clear picture of human modification of landscapes through many interventions. This region displays evidence of the some of the earliest plant cultivation, many of which leave telltale signals in pollen and macrobotanical records. Further, early evidence of water management and burning connected with pastoralism have acted as a filter on species composition of local vegetation and ecosystems for thousands of years. Deeper connections between the palaeoecological record, archeological data, and anthropological theory through continued empirical data generation and combined empirical and modeling approaches could prove extremely helpful for bettering understanding feedbacks between changing human demography, culture, and the natural environment.

Finally, we observe that Arabian landscapes, particularly semi-desert and desert ecosystems today are extremely fragile; however, they show an overall strong resilience throughout the Holocene as observed through the lens of the palaeoecological record. However, while some land-use practices have been observed by pollen data to degrade resource-rich landscapes such as intensive agriculture, other forms of traditional management alternately enriched landscapes, such as water management for agriculture and pastoralism. Palaeoecology in Arabia provides an important perspective and framework for lessons in sustainable management of dryland ecosystems under changing climate in the future.

\section{ACKNOWLEDGMENTS}

This work contributes to the ACCEDE ANR-NSF Belmont Forum project (18 BELM 000105 and NSF-1929563) as well as NSF-CNH 1617185. Thanks are due to the African Pollen Database for data access. SJI is funded by Penn State University, AML is funded by CNRS, MD is funded by the DFG priority program SPP Entangled Africa.

\section{REFERENCES}

Abuelgasim, A., Ross, W., Gopal, S. and Woodcock, C., 1999, Change detection using adaptive fuzzy neural networks: Environmental damage assessment after the Gulf War. Remote Sensing of Environment, 70, pp. 208-223, 10.1016/S0034-4257(99)00039-5. 
Albalawi, E., Dewan, A. and Corner, R., 2018, Spatio-temporal analysis of land use and land cover changes in arid region of Saudi Arabia. International Journal of GEOMATE, 14, pp. 73-81, $10.21660 / 2018.44 .3708$.

Almazroui, M., Nazrul Islam, M., Athar, H., Jones, P. D. and Rahman, M. A., 2012, Recent climate change in the Arabian Peninsula: annual rainfall and temperature analysis of Saudi Arabia for 1978-2009. International Journal of Climatology, 32, pp. 953-966, 10.1002/joc.3446.

Alqurashi, A. F., Kumar, L. and Sinha, P., 2016, Urban land cover change modelling using timeseries satellite images: A case study of urban growth in five cities of Saudi Arabia. Remote Sensing, 8, article: $838,10.3390 /$ rs 8100838 .

Anderson, J., 2007, Climatic and structural controls on the geomorphology of Wadi Sana, highland Southern Yemen, PhD thesis, University of South Florida.

Armitage, S., Jasim, S., Marks, A., Parker, A., Usik, V. and Uerpmann, H., 2011, The southern route "out of Africa": evidence for an early expansion of modern humans into Arabia. Science, 331, pp. 453-456, 10.1126/science.1199113.

Avni, Y., N. Porat, N., Avni, G., 2012, Pre-farming environment and OSL chronology in the Negev Highlands, Israel. Journal of Arid Environments, 86, pp. 12-27, 10.1016/j.jaridenv.2012.01.002.

Baierle, H., 1993, Vegetation und Flora im südwestlichen Jordanien. Dissertationes botanicae, 200, I-VIII.

Ball, L., MacMillan, D., Tzanopoulos, J., Spalton, A., Al Hikmani, H. and Moritz, M., 2020, Contemporary Pastoralism in the Dhofar Mountains of Oman. Human Ecology, 48, pp. 267-277, 10.1007/s10745-020-00153-5.

Bar-Matthews, M. and Ayalon, A., 2011, Mid-Holocene climate variations revealed by highresolution speleothem records from Soreq Cave, Israel and their correlation with cultural changes. The Holocene, 21, pp. 163-171, 10.1177/095683610384165.

Bar-Matthews, M., Ayalon, A., Kaufman, A. and Wasserburg, G. J., 1999, The Eastern Mediterranean paleoclimate as a reflection of regional events: Soreq cave, Israel. Earth and Planetary Science Letters, 166, pp. 85-95, 10.1016/S0012-821X(98)00275-1.

Beckers, B., Schütt, B., Tsukamoto, S. and Frechen, M. (2013): Age determination of Petra's engineered landscape optically stimulated luminescence (OSL) and radiocarbon ages of runoff terrace systems in the Eastern Highlands of Jordan. Journal of Archaeological Science 40, pp. 333-348, 10.1016/j.jas.2012.06.041.

Beech, M. and Shepherd, E., 1994, Archaeobotanical evidence for early date consumption. Antiquity, 71, pp. 288-99, 10.1017/S0003598X00052765.

Berger, A. and Loutre, M.-F., 1991, Insolation values for the climate of the last 10 million years. Quaternary Science Reviews, 10, pp. 297-317, 10.1016/0277-3791(91)90033-Q.

Berger, J. F., Bravard, J. P., Purdue, L., Benoist, A., Mouton, M. and Braemer, F., 2012, Rivers of the Hadramawt watershed (Yemen) during the Holocene: Clues of late functioning. Quaternary International, 266, pp. 142-161, 10.1016/j.quaint.2011.10.037.

Boivin, N. and Fuller, D., 2009, Shell middens, ships and seeds: Exploring coastal subsistence, maritime trade and the dispersal of domesticates in and around the ancient Arabian Peninsula. Journal of World Prehistory, 22, pp. 113-180, 10.1007/s10963-009-9018-2.

Bonnefille, R., 2010, Cenozoic vegetation, climate changes and hominid evolution in tropical Africa. Global and Planetary Change, 72, pp. 390-411, 10.1016/j.gloplacha.2010. 01.015 .

Bouchaud, C., 2011, Paysages et pratiques d'exploitation des ressources végétales en milieux semi-aride et aride dans le sud du Proche-Orient : Approche archéobotanique des périodes antique et islamique (IVe siècle av. J.-C. - XVIe siècle ap. J.-C.). Thèse, Paris 1, pp. 399.

Bouchaud, C., Dabrowski, V. and Tengberg, M., 2016, État des lieux de la recherche archéobotanique en péninsule Arabique. Actualités des recherches archéologiques en Arabie. Routes de l'Orient, 2, pp. 21-37. 
Buerkert, A. and Schlecht, E., 2010, Oases of Oman: Millenia old livelihood systems at the cossroads. Al Roya Press \& Publishing House, Muscat, Oman, pp. 145.

Burns, S., Fleitmann, D., Matter, A., Neff, U. and Mangini, A., 2001, Speleothem evidence from Oman for continental pluvial events during interglacial periods. Geology, 29, pp. 623-626, 10.1130/0091-7613(2001)029\#<0623:SEFOFC\#>2.0.CO;2.

Cao, X., Meng, Y. and Chen, J., 2015, Mapping grassland wildfire risk of the world. In World Atlas of Natural Disaster Risk, Berlin, Heidelberg, Springer, pp. 277-283.

Charbonnier, J., Purdue, L., Calastrenc, C., Regagnon, E., Sagory, T. and Benoist, A., 2017, Ancient agricultural landscapes in Southeast Arabia: Approach and first results of an archaeological, geo-archaeological, and spatial study of the Masāfi Palm Grove, Emirate of Fujairah. Proceedings of Water and Life in Arabia Conference, 14th - 16th December, Dec 2014, Abu Dhabi, United Arab Emirates. halshs-01792812.

Chen, C. and Litt, T., 2018, Dead Sea pollen provides new insights into the paleoenvironment of the southern Levant during MIS 6-5. Quaternary Science Reviews, 188, pp. 15-27, 10.1016/j.quascirev.2018.03.029.

Crassard, R. and Drechsler, P., 2013, Towards new paradigms: multiple pathways for the Arabian Neolithic. Arabian Archaeology and Epigraphy, 24, pp. 3-8, 10.1111/aae.12021.

Crassard, R., Petraglia, M., Drake, N., Breeze, P., Gratuze, B., Alsharekh, A. and Robin, C. J., 2013, Middle Palaeolithic and Neolithic occupations around Mundafan palaeolake, Saudi Arabia: implications for climate change and human dispersals. PLoS One, 8, article: e69665.

Cremaschi, M., Zerboni, A., Charpentier, V., Crassard, R., Isola, I., Regattieri, E. and Zanchetta, G., 2015, Early-Middle Holocene environmental changes and pre-Neolithic human occupations as recorded in the cavities of Jebel Qara (Dhofar, southern Sultanate of Oman). Quaternary International, 382, pp. 264-276, 10.1016/j.quaint.2014.12.058.

Dahinden, F., Fischer, E. M. and Knutti, R., 2017, Future local climate unlike currently observed anywhere. Environmental Research Letters, 12, article: 084004, 10.1088/1748-9326/aa75d7.

Davies, C., 2006, Holocene paleoclimates of southern Arabia from lacustrine deposits of the Dhamar highlands, Yemen. Quaternary Research, 66, pp. 454-464, 10.1016/j.yqres.2006. 05.007 .

Dawson, A., Paciorek, C., McLachlan, J., Goring, S., Williams, J. and Jackson, S., 2016, Quantifying pollen-vegetation relationships to reconstruct ancient forests using 19th-century forest composition and pollen data. Quaternary Science Reviews, 137, pp. 156-175, 10.1016/j.quascirev.2016.01.012.

Deil, U., 1998, Coastal and sabkha vegetation. In Vegetation of the Arabian Peninsula, edited by Ghazanfar, S.A. and Fisher, M., (Dordrecht: Springer), pp. 209-228.

Deil, U., and al Gifri, A., 1998, Montane and wadi vegetation In Vegetation of the Arabian Peninsula, edited by Ghazanfar, S.A. and Fisher, M., (Dordrecht: Springer), pp. 125-174.

deMenocal, P. and Stringer, C., 2016, Human migration: Climate and the peopling of the world. Nature, 538, pp. 49-50, 10.1038/nature19471.

Dinies, M., Plessen, B., Neef, R. and Kürschner, H., 2015, When the desert was green: Grassland expansion during the early Holocene in northwestern Arabia. Quaternary International, 382, pp. 293-302, 10.1016/j.quaint.2015.03.007.

Dinies, M., Neef, R., Plessen, B., and Kürschner, H., 2016, Holocene vegetation, climate, land use and plant cultivation in the Tayma region, northwestern Arabia. The Archaeology of North Arabia: Oases and Landscapes, edited by Luciani, M., OREA - Oriental and European Archaeology, 4, pp. 57-78.

El-Moslimany, A., 1990, Ecological significance of common nonarboreal pollen: examples from drylands of the Middle East. Review of Palaeobotany and Palynology, 64, pp. 343-350, 10.1016/0034-6667(90)90150-H. 
Engel, M., Brückner, H., Pint, A., Wellbrock, K., Ginau, A., Voss, P. and Frenzel, P., 2012, The early Holocene humid period in NW Saudi Arabia-Sediments, microfossils and palaeohydrological modelling. Quaternary International, 266, pp. 131-141, 10.1016/j.quaint.2011. 04.028.

Enzel, Y., Kushnir, Y. and Quade, J., 2015, The middle Holocene climatic records from Arabia: Reassessing lacustrine environments, shift of ITCZ in Arabian Sea, and impacts of the southwest Indian and African monsoons. Global and Planetary Change, 129, pp. 69-91, 10.1016/j.gloplacha.2015.03.004.

Feakins, S., 2013, Pollen-corrected leaf wax D/H reconstructions of northeast African hydrological changes during the late Miocene. Palaeogeography, Palaeoclimatology, Palaeoecology, 374, pp. 62-71, 10.1016/j.palaeo.2013.01.004.

Fernandes, V., Triska, P., Pereira, J. B., Alshamali, F., Rito, T., Machado, A. and Richards, M. B., 2015, Genetic stratigraphy of key demographic events in Arabia. PloS one, 10, article: e0118625, 10.1371/journal.pone.0118625.

Fersi, W., Lézine, A. M., and Bassinot, F., 2016, Hydro-climate changes over southwestern Arabia and the Horn of Africa during the last glacial-interglacial transition: A pollen record from the Gulf of Aden. Review of Palaeobotany and Palynology, 233, pp. 176-185, 10.1016/j.revpalbo.2016.04.002.

Fick, S.E. and Hijmans, R.J., 2017, WorldClim 2: new 1-km spatial resolution climate surfaces for global land areas. International Journal of Climatology, 37, pp. 4302-4315, 10.1002/joc.5086.

Fisher, M. and Membery, D., 1998, Climate. In Vegetation of the Arabian Peninsula, edited by Ghazanfar, S.A. and Fisher, M., (Dordrecht: Springer), pp. 5-38.

Fleitmann, D., Burns, S., Mangini, A., Mudelsee, M., Kramers, J., Villa, I. and Neff, U., 2007, Holocene ITCZ and Indian monsoon dynamics recorded in stalagmites from Oman and Yemen (Socotra). Quaternary Science Reviews 26, pp. 170-188, 10.1016/j.quascirev.2006.04.012.

Fleitmann, D., Burns, S., Pekala, M., Mangini, A., Al-Subbary, A., Al-Aowah, M. and Matter, A., 2011, Holocene and Pleistocene pluvial periods in Yemen, southern Arabia. Quaternary Science Reviews, 30, pp. 783-787, 10.1016/j.quascirev.2011.01.004.

Friesen, J., Zink, M., Bawain, A. and Müller, T., 2018, Hydrometeorology of the Dhofar cloud forest and its implications for groundwater recharge. Journal of Hydrology: Regional Studies, 16, pp. 54-66, 10.1016/j.ejrh.2028.03.002.

Fuller, D., Asouti, E. and Purugganan, M., 2012, Cultivation as slow evolutionary entanglement: comparative data on rate and sequence of domestication. Vegetation History and Archaeobotany, 21, pp. 131-145, 10.1007/s00334-011-0329-8.

Galletti, C., Turner, B. and Myint, S., 2016, Land changes and their drivers in the cloud forest and coastal zone of Dhofar, Oman, between 1988 and 2013. Regional Environmental Change, 16, pp. 2141-2153, 10.1007/s10113-016-0942-2.

Ghazanfar, S., 1992, Quantitative and biogeographic analysis of the flora of the Sultanate of Oman. Global Ecology and Biogeography Letters, 2, pp. 189-195, 10.2307/2997660.

Gil-López, M., Segarra-Moragues, J. and Ojeda, F., 2017, Influence of habitat patchiness on diversity patterns of a habitat specialist plant community. Journal of Vegetation Science, 28, pp. 436-444, 10.1111/jvs.12488.

Groucutt, H. and Petraglia, M., 2012, The prehistory of the Arabian peninsula: deserts, dispersals, and demography. Evolutionary Anthropology: Issues, News, and Reviews, 21, pp. 113-125, 10.1002/evan.21308.

Guagnin, M., Shipton, C., Martin, L. and Petraglia, M., 2017, The Neolithic site of Jebel Oraf 2, northern Saudi Arabia: First report of a directly dated site with faunal remains. Archaeological Research in Asia, 9, pp. 63-67, 10.1016/j.ara.2017.02.001.

Guba, I., and Glennie, K., 1998, Geology and geomorphology. In Vegetation of the Arabian Peninsula edited by Ghazanfar, S.A. and Fisher, M., (Dordrecht: Springer), pp. 39-62. 
Gupta, A., Anderson, D. and Overpeck, J., 2003, Abrupt changes in the Asian southwest monsoon during the Holocene and their links to the North Atlantic Ocean. Nature, 421, pp. 354-357, 10.1038 /nature 01340 .

Harrower, M., 2008, Mapping and dating incipient irrigation in Wadi Sana, Hadramawt (Yemen). Proceedings of the Seminar for Arabian Studies, 38, pp. 187-201.

Harrower, M., McCorriston, J. and D'Andrea, A., 2010, General/specific, local/global: comparing the beginnings of agriculture in the Horn of Africa (Ethiopia/Eritrea) and southwest Arabia (Yemen). American Antiquity, pp. 452-472, 10.7183/0002-7316.75.3.452.

Hausleiter, A. and Eichmann, R., 2018, The archaeological exploration of the oasis of Tayma. In Taymā' 1. Archaeological Exploration, Palaeoenvironment, Cultural Contacts, edited by Hausleiter, A., Eichmann, R. and al-Najem, M. (Oxford: Archaeopress Publishing LTD), pp. 3-58.

Hély, C., and Lézine, A.-M., 2014, Holocene changes in African vegetation: Tradeoff between climate and water availability. Climate of the Past, 10, pp. 681-686, 10.5194/cp-10-681-2014.

Hildebrandt, A., Al Aufi, M., Amerjeed, M., Shammas, M., and Eltahir, E., 2007, Ecohydrology of a seasonal cloud forest in Dhofar: 1. Field experiment. Water Resources Research, 43. W10411, 10.1029/2006WR005261.

Hillman, G., Hedges, R., Moore, A., Colledge, S., and Pettitt, P., 2001, New evidence of Lateglacial cereal cultivation at Abu Hureyra on the Euphrates. The Holocene, 11, pp. 383-393, 10.1191/095968301678302823.

Hoelzmann, P., Jolly, D., Harrison, S., Laarif, F., Bonnefille, R. and Pachur, H., 1998, MidHolocene land-surface conditions in northern Africa and the Arabian Peninsula: A data set for the analysis of biogeophysical feedbacks in the climate system. Global biogeochemical cycles, 12, pp. 35-51, 10.1029/97GB02733.

Hoorn, C. and Cremaschi, M., 2004, Late Holocene palaeoenvironmental history of Khawr Rawri and Khawr Al Balid (Dhofar, Sultanate of Oman). Palaeogeography, Palaeoclimatology, Palaeoecology, 213, pp. 1-36, 10.1016/j.palaeo.2004.03.014.

Huang, J., Li, Y., Fu, C., Chen, F., Fu, Q., Dai, A. and Zhang, L., 2017, Dryland climate change: Recent progress and challenges. Reviews of Geophysics, 55, pp. 719-778, 10.1002/2016RG000550.

Hunt, C., Elrishi, H., Gilbertson, D., Grattan, J., McLaren, S., Pyatt, F. and Barker, G. W., 2004, Early-holocene environments in the Wadi Faynan, Jordan. The Holocene, 14, pp. 921-930, 10.1191/0959-683604hl769rp.

Hunt, C., Gilbertson, D. and El-Rishi, H., 2007, An 8000-year history of landscape, climate, and copper exploitation in the Middle East: The Wadi Faynan and the Wadi Dana National Reserve in southern Jordan. Journal of Archaeological Science, 34, pp. 1306-1338, 10.1016/j.jas.2006.10.022.

Huntley, B., 1990, European vegetation history: Palaeovegetation maps from pollen data-13 000 yr BP to present. Journal of Quaternary Science, 5, pp. 103-122, 10.1002/jqs.3390050203.

Issar, A. S. and Bruins, H. J., 1983, Special climatological conditions in the deserts of Sinai and the Negev during the latest Pleistocene. Palaeogeography, Palaeoclimatology, Palaeoecology, 43(1-2), pp. 63-72, 10.1016/0031-0182(83)90048-2.

Ivory, S., Lézine, A.-M., Grimm, E. and Williams, J.W., 2020, Relaunching the African pollen database: abrupt change in climate and ecosystems. PAGES, 51, pp. 26-35.

Ivory. S., Cole, K., Anderson, R.S., Anderson, A. and McCorriston, M., 2021, Human landscape modification and expansion of tropical woodland in southern Arabia during the mid-Holocene from rock hyrax (Procavia capensis) middens, Journal of Biogeography, 10.1111/jbi.14226.

Kimiaie, M. and McCorriston, J., 2014, Climate, human palaeoecology and the use of fuel in Wadi Sana, Southern Yemen. Vegetation History and Archaeobotany, 23, pp. 33-40, 10.1007/s00334013-0394-2. 
Kislev, M., Hartmann, A. and Bar-Yosef, O., 2006, Early domesticated fig in the Jordan valley. Science, 312, pp. 1372-1374, 10.1126/science.1125910.

Kuerschner, H., 1998, Biogeography and Introduction to Vegetation. In Vegetation of the Arabian Peninsula, edited by Ghazanfar, S.A. and Fisher, M., (Dordrecht: Springer), pp. 63-98.

Lambeck, K., 1996, Shoreline reconstructions for the Persian Gulf since the last glacial maximum. Earth and Planetary Science Letters, 142, pp. 43-57, 10.1016/0012-821X(96)00069-6.

Lézine, A.-M., 2009, Timing of vegetation changes at the end of the Holocene Humid Period in desert areas at the northern edge of the Atlantic and Indian monsoon systems. Comptes Rendus Geosciences, 341, pp. 750-759, 10.1016/j.crte.2009.01.001.

Lézine, A.-M., Saliège, J., Robert, C., Wertz, F., and Inizan, M. L., 1998, Holocene lakes from Ramlat as-Sab'atayn (Yemen) illustrate the impact of monsoon activity in southern Arabia. Quaternary Research, 50, pp. 290-299, 10.1006/qres.1998.1996.

Lézine, A.-M., Saliège, J., Mathieu, R., Tagliatela, T., Mery, S., Charpentier, V. and Cleuziou, S., 2002, Mangroves of Oman during the late Holocene: climatic implications and impact on human settlements. Journal of Vegetation History and Archaeobotany 11, pp. 221-232, $10.1007 / \mathrm{s} 003340200025$.

Lézine, A.-M., Tiercelin, J.J., Robert, C., Saliège, J.F., Cleuziou, S., Inizan, M.L. and Braemer, F., 2007, Centennial to millennial-scale variability of the Indian monsoon during the early Holocene from a sediment, pollen and isotope record from the desert of Yemen. Palaeogeography, Palaeoclimatology, Palaeoecology, 243, pp. 235-249, 10.1016/j.palaeo.2006.05.019.

Lézine, A.-M., Robert, C., Cleuziou, S., Inizan, M., Braemer, F., Saliège, J.F. and Charpentier, V., 2010, Climate change and human occupation in the Southern Arabian lowlands during the last deglaciation and the Holocene. Global and Planetary Change, 72, pp. 412-428, 10.1016/j.gloplacha.2010.01.016.

Lézine, A.-M., Bassinot, F. and Peterschmitt, J.Y., 2014, Orbitally-induced changes of the Atlantic and Indian monsoons over the past 20,000 years: New insights based on the comparison of continental and marine records. Bulletin de la Société Géologique de France, 185, pp. 3-12, 10.2113/gssgfbull.185.1.3.

Lézine, A.-M., Ivory, S., Braconnot, P. and Marti, O., 2017, Timing of the southward retreat of the ITCZ at the end of the Holocene Humid Period in Southern Arabia: Data-model comparison. Quaternary Science Reviews, 164, pp. 68-76, 10.1016/j.quascirev.2017.03.019.

Lippi, M., Bellini, C., Benvenuti, M. and Fedi, M., 2011, Palaeoenvironmental signals in ancient urban setting: the heavy rainfall record in Sumhuram, a pre-Islamic archaeological site of Dhofar (S Oman). The Holocene, 21, pp. 951-965, 10.1177/0959683611400203.

Litt, T., Ohlwein, C., Neumann, F. H., Hense, A. and Stein, M., 2012, Holocene climate variability in the Levant from the Dead Sea pollen record. Quaternary Science Reviews, 49, pp. 95-105, 10.1016/j.quascirev.2012.06.012.

Lokier, S., Bateman, M., Larkin, N., Rye, P. and Stewart, J., 2015, Late Quaternary sea-level changes of the Persian Gulf. Quaternary Research, 84, pp. 69-81, 10.1016/j.yqres.2015. 04.007.

Mandaville, J., 1998, Vegetation of the sands. In Vegetation of the Arabian Peninsula, edited by Ghazanfar, S.A. and Fisher, M., (Dordrecht: Springer), pp. 191-282.

Martin, L., McCorriston, J. and Crassard, R., 2009, Early Arabian pastoralism at Manayzah in Wādī Șanā, Haḍramawt. In Proceedings of the Seminar for Arabian Studies. Archaeopress, pp. 271-282.

Mayewski, P., Rohling, E., Stager, J., Karlén, W., Maasch, K., Meeker, L. and Lee-Thorp, J., 2004, Holocene climate variability. Quaternary Research, 62, pp. 243-255, 10.1016/j.yqres. 2004.07.001.

McClure, H., 1984, Late Quaternary palaeoenvironments of the Rub'Al Khali; PhD, University College London, UK. 
McCorriston, J., 2013, The Neolithic in Arabia: a view from the south. Arabian Archaeology and Epigraphy, 24, pp. 68-72, 10.1111/aae.12012.

McCorriston, J., and Johnson, Z., 1998, Agriculture and animal husbandry at Ziyadid Zabid, Yemen. Proceedings of the Seminar for Arabian Studies, 28, pp. 175-188.

McCorriston, J., Walter, D., Oches, E., and Cole, K., 2002, Holocene paleoecology and prehistory in highland southern Arabia. Paléorient, 28(1), pp. 61-88, 10.3406/paleo.2002.4739.

Meister, J., Krause, J., Müller-Neuhof, B., Portillo, M., Reimann, T. and Schütt, B., 2016, Desert agricultural systems at EBA Jawa (Jordan): Integrating archaeological and paleoenvironmental records. Quaternary International 434, pp. 33-50, 10.1016/j.quaint.2015.12.086.

Migowski, C., Agnon, A., Bookman, R., Negendank, J. F. and Stein, M., 2004, Recurrence pattern of Holocene earthquakes along the Dead Sea transform revealed by varve-counting and radiocarbon dating of lacustrine sediments. Earth and Planetary Science Letters, 222, pp. 301-314, 10.1016/j.epsl.2004.02.015.

Mittermeier, R., Turner, W., Larsen, F., Brooks, T. and Gascon, C., 2011, Global biodiversity conservation: the critical role of hotspots. In Biodiversity hotspots, (Berlin and Heidelberg: Springer), pp. 3-22.

Moraetis, D., Al Kindi, S., Al Saadib, S., Al Shaibani, A., Pavlopoulos, K., Scharf, A., Mattern, F., Harrower, M. and Pracejus, B., 2020, Terrace agriculture in a mountainous arid environment - A study of soil quality and regolith provenance: Jabal Akhdar (Oman). Geoderma 363, pp. 1141-1152, 10.1016/j.geoderma.2019.114152.

Neff, U., Burns, S. J., Mangini, A., Mudelsee, M., Fleitmann, D. and Matter, A., 2001, Strong coherence between solar variability and the monsoon in Oman between 9 and 6 kyr ago. Nature, 411, pp. 290-293, 10.1038/35077048.

Nellessen, T., 2013, The Consciousness of Water: Narrative Flows, Environmental Change, and the Voice of Yemen. $\mathrm{PhD}$ thesis, University of Arkansas, USA.

Oberprieler, C., Meister, J., Schneider, C. and Kilian, N., 2009, Genetic structure of Anogeissus dhofarica (Combretaceae) populations endemic to the monsoonal fog oases of the southern Arabian Peninsula. Biological Journal of the Linnean Society, 97, pp. 40-51, 10.1111/j.10958312.2008.01173.x.

Olson, D.M., Dinerstein, E., Wikramanayake, E.D., Burgess, N.D., Powell, G.V.N., Underwood, E.C., D’Amico, J.A., Itoua, I., Strand, H.E., Morrison, J.C., Loucks, C.J., Allnutt, T.F., Ricketts, T.H., Kura, Y., Lamoreux, J.F., Wettengel, W.W., Hedao, P. and Kassem, K.R., 2001, Terrestrial ecoregions of the world: a new map of life on Earth. Bioscience, 51, pp. 933-938, 10.1641/0006-3568(2001)051[0933:TEOTWA]2.0.CO;2.

Pachauri, R.K., Allen, M.R., Barros, V.R., Broome, J., Cramer, W., Christ, R., Church, J.A., Clarke, L., Dahe, Q., Dasgupta, P. and Dubash, N.K., 2014, Climate change 2014: synthesis report. Contribution of Working Groups I, II and III to the fifth assessment report of the Intergovernmental Panel on Climate Change (p. 151).

Parker, A., Eckersley, L., Smith, M., Goudie, A., Stokes, S., Ward, S. and Hodson, M., 2004, Holocene vegetation dynamics in the northeastern Rub'al-Khali desert, Arabian Peninsula: a phytolith, pollen and carbon isotope study. Journal of Quaternary Science, 19, pp. 665-676.

Parker, A., 2010, Pleistocene climate change in Arabia: developing a framework for hominin dispersal over the last $350 \mathrm{ka}$. In The evolution of human populations in Arabia, edited by Petraglia, M.D. and Rose, J.I., (Dordrecht: Springer), pp. 39-49.

Parker, A., Goudie, A., Stokes, S., White, K., Hodson, M., Manning, M. and Kennet, D.. 2006, A record of Holocene climate change from lake geochemical analyses in southeastern Arabia. Quaternary Research, 66, pp. 465-476, 10.1016/j.yqres.2006.07.001.

Patzelt, A., 2015, Synopsis of the flora and vegetation of Oman, with special emphasis on patterns of plant endemism. Abhandlungen der Braunschweigischen Wissenschaftlichen Gesellschaft, 282, pp. 317. 
Pausata, F., Zanchettin, D., Karamperidou, C., Caballero, R., and Battisti, D., 2020, ITCZ shift and extratropical teleconnections drive ENSO response to volcanic eruptions. Science Advances, 6, eaaz5006, 10.1126/sciadv.aaz5006.

Petit-Maire, N., Carbonel, P., Reyss, J. L., Sanlaville, P., Abed, A., Bourrouilh, R. and Yasin, S., 2010, A vast Eemian palaeolake in Southern Jordan (29 N). Global and Planetary Change, 72, pp. 368-373, 10.1016/j.gloplacha.2010.01.012.

Petraglia, M., 2011, Trailblazers across Arabia. Nature, 470, pp. 50-51, 10.1038/470050a.

Petraglia, M., Groucutt, H., Guagnin, M., Breeze, P. and Boivin, N., 2020, Human responses to climate and ecosystem change in ancient Arabia. Proceedings of the National Academy of Sciences, 117, pp. 8263-8270, 10.1073/pnas.1920211117.

Pietsch, D., Kühn, P., Scholten, T., Brunner, U., Hitgen, H. and Gerlach, I., 2010, Holocene soils and sediments around Ma'rib Oasis, Yemen: Further Sabaean treasures? The Holocene, 20, pp. 785-799, 10.1177/0959683610362814.

Preusser, F., Radies, D. and Matter, A., 2002, A 160,000-year record of dune development and atmospheric circulation in Southern Arabia. Science, 296, pp. 2018-2020, 10.1126/science. 1069875 .

Purdue, L., Charbonnier, J., Régagnon, E., Calastrenc, C., Sagory, T., Virmoux, C., Crépy, M., Costa, S. and Benoist, A., 2019, Geoarchaeology of Holocene oasis formation, hydroagricultural management and climate change in Masafi, southeast Arabia (UAE). Quaternary Research, 92, pp. 109-132, 10.1017/qua.2018.142.

Roberts, A., Rohling, E., Grant, K., Larrasoaña, J. and Liu, Q., 2011, Atmospheric dust variability from Arabia and China over the last 500,000 years. Quaternary Science Reviews, 30, pp. 3537-3541, 10.1016/j.quascirev.2011.09.007.

Robinson, S., Black, S., Sellwood, B. and Valdes, P., 2006, A review of palaeoclimates and palaeoenvironments in the Levant and Eastern Mediterranean from 25,000 to 5000 years BP: setting the environmental background for the evolution of human civilisation. Quaternary Science Reviews, 25, pp. 1517-1541, 10.1016/j.quascirev.2006.02.006.

Rose, J. and Usik, V., 2010, The "Upper Paleolithic" of South Arabia. In The evolution of human populations in Arabia, (Dordrecht: Springer), pp. 169-185.

Rosenberg, T., Preusser, F., Fleitmann, D., Schwalb, A., Penkman, K., Schmid, T. and Matter, A., 2011, Humid periods in southern Arabia: windows of opportunity for modern human dispersal. Geology, 39, pp. 1115-1118, 10.1130/G32281.1.

Rossignol-Strick, M., 1999, The Holocene climatic optimum and pollen records of sapropel 1 in the eastern Mediterranean, 9000-6000 BP. Quaternary Science Reviews, 18, pp. 515-530, 10.1016/S0277-3791(98)00093-6.

Sander, K., 2006, Holocene climate and hydrologic changes recorded in Tufa and Lacustrine deposits in Southern Yemen. PhD diss., University of South Florida, USA.

Schiettecatte, J., 2013, Le palmier dattier (Phoenix dactylifera L.) dans l'Arabie méridionale préislamique. Revue d'ethnoécologie, 4, 1356, 10.4000/ethnoecologie.

Schiettecatte, J., Chabrol, A., and Fouache, É., 2013, Landscape and settlement process in alKharj oasis (province of Riyadh). In The Archaeology of North Arabia, Oases and Landscapes, edited by Luciani, M., (Vienna: Verlag der Österreichischen Akademie der Wissenschaften), pp. 257-280.

Schulz, E., and Whitney, J., 1987, Upper Pleistocene and Holocene lakes in the an Nafud, Saudi Arabia. Paleolimnology, 4, pp. 175-190, 10.1007/BF00026660.

Scotese, C. and Golonka, J., 1997, Paleogeographic atlas (pp. 1-45). Arlington: PALEOMAP Project, University of Texas at Arlington.

Sirocko, F., Sarnthein, M., Erlenkeuser, H., Lange, H., Arnold, M. and Duplessy, J., 1993, Century-scale events in monsoonal climate over the past 24,000 years. Nature, 364, pp. 322 $324,10.1038 / 364322 \mathrm{a} 0$. 
Stevens, L., Ito, E., Schwalb, A. and Wright Jr, H., 2006, Timing of atmospheric precipitation in the Zagros Mountains inferred from a multi-proxy record from Lake Mirabad, Iran. Quaternary Research, 66, pp. 494-500, 10.1016/j.yqres.2006.06.008.

Stokes, S. and Bray, H., 2005, Late Pleistocene eolian history of the Liwa region, Arabian Peninsula. Geological Society of America Bulletin, 117, pp. 1466-1480, 10.1130/B25554.1.

Tengberg, M., 2003, Archaeobotany in the Oman peninsula and the role of Eastern Arabia in the spread of African crops. Food, fuel and fields: Progress in African archaeobotany, pp.229-238.

Thalen, D., 1979, Ecology and utilization of desert shrub rangelands in Iraq, (The Hague: Dr. W. Junk. Publishers), 428 p.

Tierney, J., deMenocal, P. and Zander, P., 2017, A climatic context for the out-of-Africa migration. Geology, 45, pp. 1023-1026, 10.1130/G39457.1.

Uerpmann, H., Potts, D. and Uerpmann, M., 2010, Holocene (re-) occupation of eastern Arabia. In The evolution of human populations in Arabia, edited by Petraglia, M.D., Rose, J.I. (Dordrecht, Springer), pp. 205-214.

Van Campo, E., Duplessy, J. and Rossignol-Strick, M., 1982, Climatic conditions deduced from a 150-kyr oxygen isotope-pollen record from the Arabian Sea. Nature, 296, pp. 56-59, $10.1038 / 296056 \mathrm{a} 0$.

Van Zeist, W., and Bottema, S., 1977, Palynological investigations in western Iran. Palaeohistoria, 19, pp. 19-85.

Watrin, J., Lézine, A.M. and Hély, C., 2009, Plant migration and plant communities at the time of the "green Sahara". Comptes Rendus Geoscience, 341, pp. 656-670, 10.1016/j.crte.2009. 06.007 .

Webb III, T. and McAndrews, J., 1976, Corresponding patterns of contemporary pollen and vegetation in central North America. Geological Society of America Memoir, 145, pp. 267-299, 10.1130/MEM145-p267.

Willcox, G., 2012, The beginnings of cereal cultivation and domestication in Southwest Asia. $A$ companion to the archaeology of the ancient Near East, 1, pp. 163-180.

Williams, J.W. and Jackson, S., 2007, Novel climates, no-analog communities, and ecological surprises. Frontiers in Ecology and the Environment, 5, pp. 475-482, 10.1890/070037.

Wilkinson, M., Dumontier, M., Aalbersberg, I., Appleton, G., Axton, M., Baak, A. and Bouwman, J., 2016, The FAIR Guiding Principles for scientific data management and stewardship. Scientific data, 3, pp. 1-9, 10.1038/sdata.2016.18.

Zeder, M., 2011, The origins of agriculture in the Near East. Current Anthropology, 52, pp. S221-S235, 10.1086/659307.

Zohary, M., 1982, Vegetation of Israel and Adjacent Areas. (Wiesbaden: Dr. Ludwig Reichert Verlag). 